\title{
EVOLUTION OF ILLITE/SMECTITE FROM EARLY DIAGENESIS THROUGH INCIPIENT METAMORPHISM IN SEDIMENTS OF THE BASQUE-CANTABRIAN BASIN
}

\author{
F. Nieto ${ }^{1}$, M. Ortega-Huertas ${ }^{1}$, D. R. Peacor ${ }^{2}$ and J. Arostegui ${ }^{3}$ \\ ${ }^{1}$ Departamento Mineralogia y Petrologia and I.A.C.T. Universidad de Granada-C.S.I.C. \\ 18002 Granada, Spain. \\ ${ }^{2}$ Department of Geological Sciences. The University of Michigan, \\ Ann Arbor, Michigan 48109, USA. \\ ${ }^{3}$ Departamento Mineralogia y Petrologia. Universidad del Pais Vasco. \\ Lejona, Bilbao, Spain.
}

\begin{abstract}
Prograde evolution of illite/smectite occurring in an unusually-thick $(8000 \mathrm{~m})$ sequence of Mesozoic-Cenozoic sediments in the Basque-Cantabrian Basin, Spain, has been studied using XRD and TEM/AEM. The sediments, which are only slightly tilted, cover the range from smectite to illite, and the most deeply buried ones are unique in that they span the range from diagenesis through low-grade metamorphism (anchizone), with no apparent overprinting due to tectonic deformation.

Pelites are absent from the shallow section, but smectite occurs in marls as high-charge, K-dominant and low-charge, K-poor anastomosing arrays of layers. At intermediate depths, authigenic clay is identified largely as R1 I/S, coexisting with packets of R $\gg 3 \mathrm{I} / \mathrm{S}$ (nearly pure illite), where illite-like and smectitelike layers can be identified by contrast in TEM images, which is consistent with XRD data. The authigenic clay of the deepest samples consists of illite with no or almost no expandable layers, which occurred as packets with layers largely subparallel to bedding, $\mathrm{K}$-deficient composition in comparison with muscovite, $1 \mathrm{M}_{\mathrm{d}}$-like SAED patterns, and $100 \AA$ mean packet thickness. There is no evidence of deformation stress-induced, non-bedding-parallel clays in the deepest samples. Detrital micas with either a phengiterich or a phengite-poor composition range dominate the phyllosilicate fraction of all the samples. Detrital micas show no changes over the diagenesis/metamorphism range and appear to have behaved as if isolated from authigenic clays.

Authigenic clays occur as bedding-subparallel packets that evolved during passive burial metamorphism through dissolution/crystallization of less-evolved clays. Where illite-like and smectite-like layers can be identified, TEM images imply a discontinuous series in which packets of R1 I/S (50\% I) transform to packets of nearly-pure illite, that is, an Ostwald-step-rule-like sequence. Such immature illite remains unmodified with further burial, and is apparently the potential predecessor of stress-induced, highlyevolved mica of higher-grade, tectonically-deformed pelites.
\end{abstract}

Key Words-Basque Cantabrian Basin, Diagenesis, Illite, Smectite.

\section{INTRODUCTION}

The complex, heterogeneous clay fractions of finegrained pelitic sediments containing phyllosilicates such as smectite, kaolinite, chlorite, micas and various mixed-layered materials, evolve during diagenesis and low grade metamorphism toward a rather simple mineral assemblage with white micas and chlorite as principal phyllosilicates. Much of the research on prograde mineral transformations occurring in the zone of diagenesis has been concerned with the transition from smectite to illite. The Gulf Coast sequence has served as a type sequence for studies of mudstones, in contrast to relatively porous sandstones, initially by indirect characterization methods (Powers 1967; Perry and Hower 1970; Hower et al. 1976; Boles and Franks 1979) and more recently using direct TEM observations and AEM analyses (Ahn and Peacor 1986; Bell 1986; Freed and Peacor 1992). Studies carried out on other sequences have confirmed the general nature of the smectite to illite transformation (Foscolos et al.
1976; Suchecki et al. 1977; Heling 1978; Srodon and Eberl 1984; Jennings and Thompson 1986; Ramseyer and Boles 1986). Chamley (1989) summarized the most important conclusions regarding the Gulf Coast and other sequences.

HRTEM data for continuous, fine-grained shale sequences other than that of the Gulf Coast are scarce (Yau et al. 1987, Salton Sea; Lindgren and Hansen 1991, North Sea). Studies of a variety of sequences are essential in order to determine the significance of factors such as initial sediment lithology and subsequent tectonic history. As regards the latter, there are in general two kinds of sequences: 1) Those involving relatively passive sedimentation without significant tectonic input. The Gulf Coast sequence is typical, with transformation of smectite to illite-rich $\mathrm{I} / \mathrm{S}$ over a narrow depth range, and with little or no subsequent change in clays after further burial, although Eberl (1993) discussed the possibility of changes in illite caused by Ostwald ripening. Mudstones of such dia- 
genetic grade may remain unchanged, for example, the 1.1 Gya-old Nonesuch shale of Michigan (Li et al. 1994). Such sequences are generally the concern of sedimentary petrologists; and 2) Sequences involving changes caused by tectonic stress. The principal lithological change is a production of slaty cleavage as a result of dissolution of bedding-parallel phyllosilicates and crystallization of more mature phyllosilicates with normal orientation to tectonic stress. Sequences covering the range from late diagenesis to anchizone to epizone through greenschist facies (Merriman and Roberts 1985, Welsh sedimentary basin; Islam et al. 1982, metasediments of the Gaspé Peninsula, Quebec) are well-known and are generally the concern of structural geologists and tectonophysicists.

However, there is a general lack of studied sequences spanning the range from passive sedimentation through tectonically-deformed sequences corresponding to the middle stages of diagenesis through anchizonal conditions. This is in some ways understandable, as very deeply buried basin sediments $(>6000 \mathrm{~m})$ are generally not available for study. Whereas the tectonic activity required to raise and expose deeply-buried sediments leads to alteration of lower-grade sediments and destruction or at least significant overprinting of diagenetic features.

The Mesozoic-Cenozoic sediment sequence from the Basque-Cantabrian Basin is therefore especially suitable for studies of prograde transformations in dioctahedral phyllosilicates. An exceptionally thick sequence of sediments is more or less continuously exposed $(8000 \mathrm{~m})$ with no detectable tectonic overprint and the shallowest sediments contain smectite. Transformation of smectite to R1 US through US with $>95 \%$ illite layers (virtually pure illite) takes place. The most deeply buried sediments attained anchizone grade (Aróstegui et al. 1991). The sediments thus bridge the gap in a sequence extending from shallow burial diagenesis through very low grade metamorphism, but without the influence of tectonic stress. We have carried out a study of the clay minerals as a function of depth, principally using TEM/AEM methods, in order to determine the changes occurring over the full range of burial metamorphism. The Basque-Cantabrian pelitic sediments are also unusual in that they consist of a large proportion of detrital materials derived from emergent eroded domains consisting of plutonic igneous and low-grade metamorphic rocks. Detrital mature micas dominate the shales and provide an opportunity to study the behavior of such materials over a wide range of diagenesis/low-grade metamorphism in contrast to transformations of clays in which detrital smectite, or smectite derived from volcanogenic materials is a reactant, as in Gulf Coast sediments.

\section{GEOLOGICAL SETTING}

The geological history of the Basque-Cantabrian Basin is linked with the general evolution of the Bay of Biscay (Deregnaucourt and Boillot 1982) across which the boundary between the Iberian and European plates is located. Lower Cretaceous to Lower Miocene sediments accumulated in the Basque-Cantabrian $\mathrm{Ba}$ $\sin$. Thicknesses range from $10,000 \mathrm{~m}$ for the northern and central sectors to $2,000 \mathrm{~m}$ for the southern sector as a result of the differences in subsidence and sedimentation rates related to the opening and closing of the Bay of Biscay within the overall geotectonic evolution of the central Atlantic Ocean.

Aróstegui et al. (1991) presented data on clay mineral occurrences for the central region of the basin (Figure 1-I, cross-section A-A') with special emphasis on the distribution and type of illite/smectite (U/S) mixed-layered material. They concluded that prograde evolution ranges, in a south to north trend, from shallow diagenesis to anchimetamorphism and that the diagenetic changes are related to temperature, subsidence rate and lithology. According to Aróstegui et al. (1991), the variations in the Basque-Cantabrian Basin of various forms of $\mathrm{I} / \mathrm{S}$ and the Kübler index (KI) are governed by the general trends shown in Figure 1-II.

The increase in the proportion of R3 I/S with increasing depth indicates that burial diagenesis was responsible for increasing maturation of the sediments with depth. For the deepest sequences from the center of the basin, nearly pure illite is found and the KI correspond to the anchizone. In addition, Aróstegui et al. (1993) pointed out that samples occur, particularly in the Lower-Middle Albian, with $R=1 \mathrm{I} / \mathrm{S}$ and "unusually" high KI values sandwiched between strata within which $\mathrm{L} / \mathrm{S}$ is of the R3 type. The $\mathrm{KI}$ does not evolve continuously with depth, but exhibits discontinuities and reversals, especially in the basin-edge sections (Figure 1-III). The local discontinuities are inferred to be due to a change in sedimentary regime that caused an increase in the detrital character of the sequence (Aróstegui et al. 1993). Consequently, the clay fraction is composed of a high proportion of dioctahedral detrital mica, as demonstrated by chemical analyses of both bulk sample and clay fraction that show a significant increase in the potassium content (Aróstegui et al. 1993) coinciding with the break in the trend of the KI values and the presence of shallow R3 I/S mixed-layer.

The high quantity of detrital mica causes a high, narrow $10 \AA$ peak in X-ray diffraction (XRD) diagrams leading to: 1) decrease of the KI; and 2) eclipse of the R1 I/S peak. The data included in Figures 1-II and 1-III are obtained by XRD. Interpretation of the lack of a continuous evolution of the $\mathrm{KI}$ and the I/S type is, in fact, one of the main aims of this study. All the data presented hereafter in this paper (Tables 3 and 4, and Figures 5, 6, 7 and 9) demonstrate continuous diagenetic evolution and the presence of R1 L/S mixedlayer in the samples whose major $\mathrm{I} / \mathrm{S}$ type was R3, according to XRD as presented in Figure 1-III. 


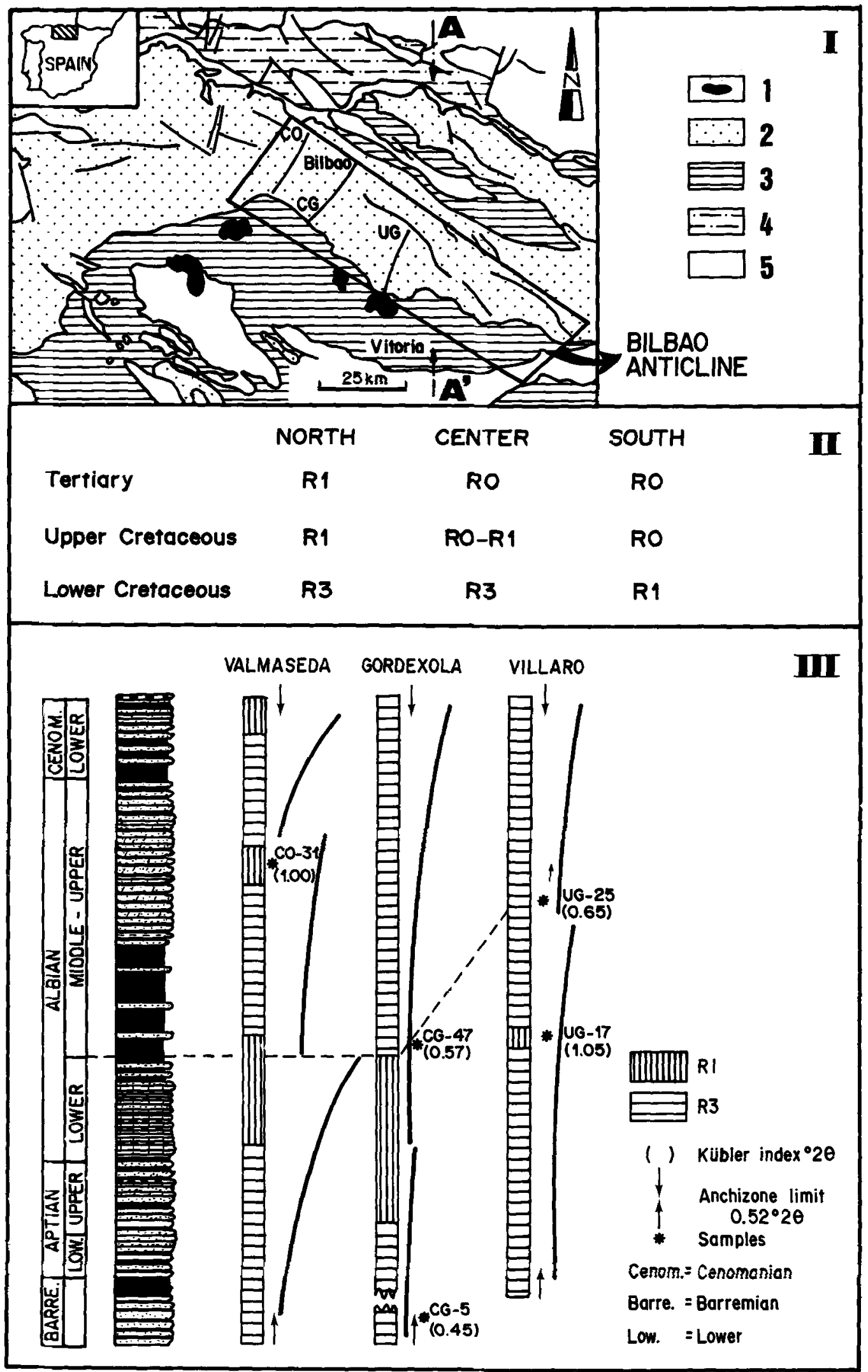




\section{MATERIALS AND METHODS}

Samples representing the full sequence of evolved dioctahedral clay minerals and the full range of $\mathrm{KI}$ values from the bottom to the top of the section were chosen for HRTEM study on the basis of the XRD data (Aróstegui et al. 1991, 1993). These samples included one smectite-rich sample (L-1, at the top of the sequence), 4 mixed-layered I/S samples (CO-31, 1410 m; UG-25, $1880 \mathrm{~m}$; UG-17, $2905 \mathrm{~m}$; and CG-47, 3047 $\mathrm{m})$ and 1 illite-rich sample (CG-5, $8010 \mathrm{~m})$. The number of meters following each sample number is the approximate maximum depth of burial, established according to regional geological criteria. Samples were also selected to represent the central thicker section (CG samples) and lateral sectors (CO and UG samples). Samples UG-17 and CO-31 are representative of the levels containing R1 I/S and were taken from strata located between levels containing only R3 I/S.

Due to the lithologic differences between the Lower Cretaceous and the upper part of the sequence, shale samples were only available for the range from R1 I/S through R3 I/S (as determined by XRD; see new interpetations below as determined by TEM). Although lithology may be an important factor in determining the transformation rate of clay minerals, we have included a marl sample from the upper part of the section, as no other kinds of clay-containing samples occur in the shallow part of the sequence, and because the occurrence of smectite in these shallow rocks is consistent with the overall trend of I/S composition in the sequence. According to previous XRD studies (Aróstegui et al. 1993), all samples chosen as representative of the mixed-layer $\mathrm{I} / \mathrm{S}$ part of the sequence contain R3 I/S, whereas samples CO-31 and UG-17 also contain R1 I/S. Sample CG-5 gives an asymmetric $10 \AA$ XRD peak that is unaffected by ethylene-glycol treatment. The dioctahedral clay therefore contains at least $95 \%$ illite layers and is nearly end-member illite according to the criteria of Reynolds (1980). Such small differences in smectite layer proportions cannot be distinguished by XRD, and we refer to this material as illite for the sake of simplicity. This is especially significant material because it formed at the greatest depth, and represents the limiting phase of the smectite to illite transformation.

\section{Transmission and Scanning Electron Microscopy}

Samples were prepared as both sticky-wax and Canada Balsam-mounted thin sections oriented approximately normal to bedding. Thin sections were examined using optical and scanning electron microscopy (SEM), including back-scattered electron (BSE) imaging and energy-dispersive X-ray (EDX) analysis. A Kevex Quantum EDX system was used for qualitative analyses. Aluminum washers were then attached to representative selected areas and the corresponding thin section areas detached through gentle heating. Samples were further thinned using a Gatan 600 ion mill and carbon-coated for TEM observation with a Philips CM-12 scanning transmission electron microscope (STEM) equipped with a Kevex Quantum solidstate EDX detector. Quantitative analyses were obtained only from thin edges, using a $50 \AA$ beam diameter and a $1000 \times 200 \AA$ scanning area, with the long axis oriented parallel to phyllosilicate packets. The sample was tilted $20^{\circ}$ toward the detector, giving an X-ray take-off angle of $34^{\circ}$. Muscovite, clinochlore, albite, fayalite, and sphene standards were used to obtain k-factors for transformation of intensity ratios to concentration ratios following the procedures of Cliff and Lorimer (1975) and Champness et al. (1981).

Loss of alkalis, especially $\mathrm{K}$, is a significant problem in analysis of clay minerals, especially for defectrich minerals such as smectite and illite (Van der Pluijm et al. 1988). Alkali deficiencies still occurred even for the analytical conditions recommended by those authors. We therefore tested the use of short counting times as is common for electron microprobe analyses (EMPA). Comparison of analyses obtained for 30 to $200 \mathrm{~s}$ showed that shorter counting times gave improved reproducibility and normalized formulae data for detrital micas were in better agreement with values expected for mica analyses. Counting times of $30 \mathrm{~s}$ were used as a compromise for analyses of alkalis because even shorter count times resulted in diminished precision.

Fine-grained powdered portions of samples CO-31 and CG-5 were also prepared using holey C-coated $\mathrm{Cu}$ grids. These samples are representative of the upper and lower portions of the shale part of the sediment sequence. The (001) layers of the clay minerals in these samples were preferentially aligned parallel to

$\leftarrow$

Figure 1. I. Geological map of the Basque-Cantabrian Basin and the area studied (Bilbao anticline): 1. Triassic; 2. Lower Cretaceous; 3. Upper Cretaceous; 4. Undated Cretaceous; 5. Tertiary. Stratigraphic studied sections: CO = Valmaseda; CG = Gordexola; UG = Villaro. II. General distribution of I/S mixed-layer kind in different ages and sectors of the BasqueCantabrian Basin, showing a general trend of increasing maturity toward the bottom of the sections, according to Aróstegui et al. (1991). III. Type-section of the Basque-Cantabrian Basin and location of the studied samples. Solid lines represent the evolution of the Kübler index (KI) with depth. Arrows point the diagenesis-anchizone limit. KI for any sample is indicated between brackets. I/S mixed-layer type was identified by X-ray diffraction (XRD) (Aróstegui et al. 1994). 


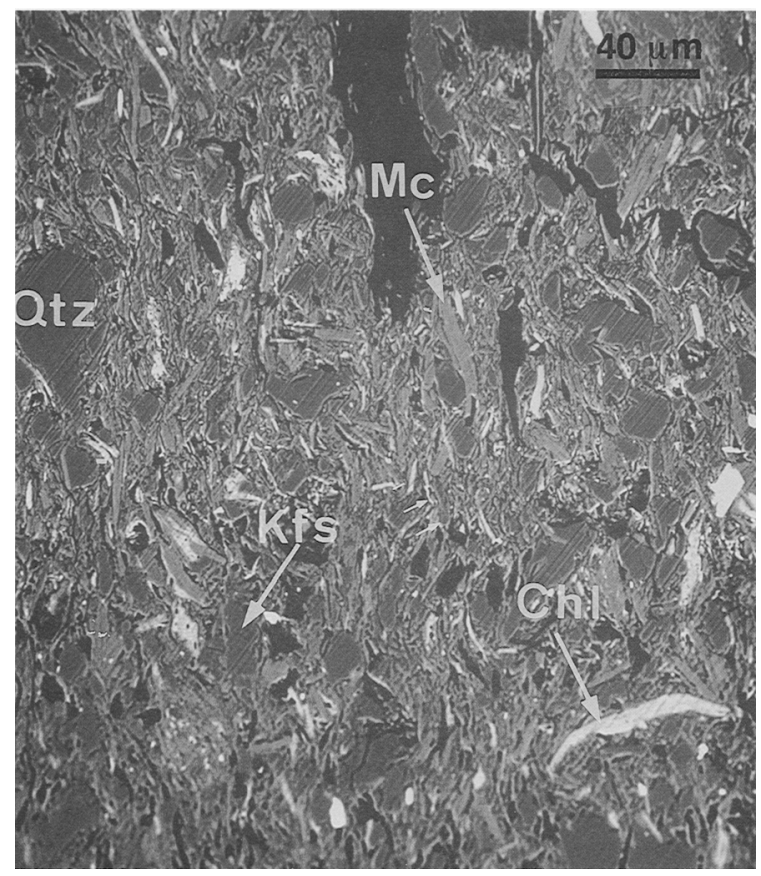

Figure 2. Backscattered electron image of sample CG-5. Mineral abbreviations according to Kretz (1983): Qtz = quartz; Chl = chlorite; $\mathrm{Kfs}=$ potassium feldspar; except Mc $=$ mica.

the sample surface. This permitted layer morphology and hk0 selected area electron diffraction (SAED) patterns to be obtained.

\section{Electron Microprobe Data for Detrital Micas}

Grains of clay minerals occurring within the finegrained matrix are too small to permit electron microprobe analysis (EMPA) of single phases, and analyses of such grains were obtained only by analytical electron microscopy (AEM). However, the larger grains of phyllosilicates of detrital origin were analyzed by EMPA so that the resulting formulae could be compared with results obtained by AEM on grains in the fine-grained matrix. Because detrital micas generally have analyses approaching those of mature micas (for example, $\mathrm{Si}:{ }^{[\mathrm{VV}]} \mathrm{Al}=3: 1$; only a small proportion of vacancies in alkali sites), whereas those of authigenic illite are Si-rich and alkali-poor, such analyses lead to differentiation between detrital and authigenic micas. EMPA analyses were carried out using a Cameca $\mathrm{Ca}$ mebax electron microprobe operated at $15 \mathrm{kv}$ and 10 $\mathrm{mA}$ beam current, using albite ( $\mathrm{Na})$, K-feldspar $(\mathrm{K})$, rhodonite $(\mathrm{Mn})$, labradorite $(\mathrm{Si}, \mathrm{Ca})$, enstatite $(\mathrm{Mg})$, andalusite (Al), synthetic geikielite ( $\mathrm{Ti}$ ) and ferrosilite $(\mathrm{Fe})$ as standards. Observed intensity data were processed using the Cameca program for the PeP procedure (Pouchou et Pichoir, authors of the procedure), which is similar to ZAF correction (Atomic numberAbsorption-Flourescence correction).

\section{RESULTS}

\section{Scanning Electron Microscopy}

No significant differences were detected among the different shale samples at the optical and scanning electron microscopy levels. Therefore, the following description of sample CG-5 (Figure 2) is representative of SEM images of all shales. All samples lack cleavage. They consist of an assemblage of detrital grains shown by EDX analyses to consist of dominant quartz and K-mica, less abundant chlorite, K-feldspar and Na-rich plagioclase $\left(\approx \mathrm{Ab}_{0.8} \mathrm{An}_{0.15} \mathrm{Or}_{0.05}\right)$, and minor amounts of $\mathrm{Ti}$ and $\mathrm{Fe}$ oxides. Clasts are generally somewhat elongated subparallel to bedding. Detrital grains range continuously in size from $50 \mu \mathrm{m}$ down through silt and clay fractions. We use the term "matrix" to describe the finest fractions, that includes the smallest detrital clastic material but is dominated by the authigenic $\mathrm{U} / \mathrm{S}$ and illite that are too fine-grained to be resolved in BSE images (see TEM data, below). The term "detrital" is used for all grains, which are largely unchanged subsequent to deposition.

High Resolution Electron Microscopy and Electron Diffraction

SMECTITE-CONTAINING MARL. TEM images show that the marl is composed of large calcite and dolomite crystals $\geq 2 \mu \mathrm{m}$ with the phyllosilicates distributed randomly throughout the carbonate matrix (Figure 3 ). Phyllosilicates of more than one kind are not intergrown and grains are randomly oriented. Three different types of clay minerals were recognized. Because each kind occurs separately within the carbonate matrix, SAED patterns, high resolution images and microanalyses could be directly correlated for each kind of clay.

I.) Highly crystalline detrital micas. These appear as coherent crystals larger than $1000 \AA$ giving welldefined SAED patterns corresponding to a two-layer (presumably $2 \mathrm{M}_{1}$ ) polytype. They present straight defect-free lattice fringes, relatively large grain size (averaging $>5000 \AA$ thick), and AEM-derived formulae corresponding to mature phengite-muscovite (Table 1, analyses L-1). These characteristics were used to identify detrital micas in all samples. No alteration or deformation was detected in these crystals.

II.) Smectite collapsed in the vacuums of the ion mill and TEM, therefore giving very diffuse $10 \AA$ (001) reflections (Figure 4a). Non-(001) reflections were not detected and basal reflections were elongated normal to $c^{*}$ as a result of curvature of smectite layers. When exposed to the electron beam, this material became damaged very rapidly and lattice fringe images could not be obtained. 


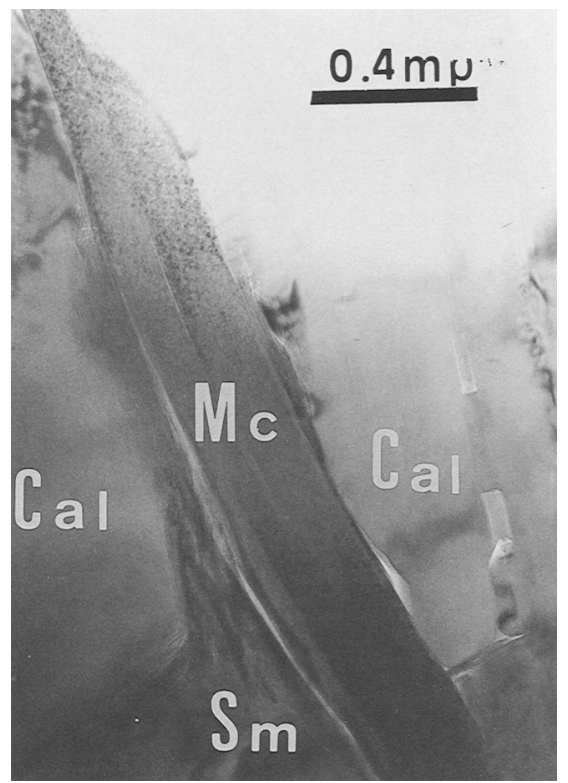

Figure 3. Low magnification TEM image representative of textural relationships between calcite and phyllosilicates in sample L-1: $\mathrm{Mc}=$ Detrital mica; $\mathrm{Sm}=$ Smectite; Cal $=$ Calcite.

III.) Non-contracted smectite was characterized by (001) SAED patterns with diffuseness parallel to $\mathrm{c}^{*}$ and periodicity of approximately $14 \AA$, but with slight displacement of reflections from perfectly rational positions (Figure $4 b$ ). This material is not subject to very rapid beam damage and high resolution images were obtained (Figure $4 \mathrm{c}$ ). The texture of this kind of smectite is similar to that described for smectite from Gulf Coast shales by Ahn and Peacor (1986), (001) fringes are anastomosing, curved and discontinuous, with variation in interplanar spacing $\left(\mathrm{d}_{001}\right)$ and contrast. The two types of smectite were found to have K-rich and $\mathrm{K}$-poor interlayers, respectively.

R1 AND R3 MIXED-LAYER I/S, SHALE SAMPLES. The finegrained clay-sized matrix is composed of stacks of subparallel packets of detrital and authigenic clays (Figure 5A). It was very difficult to find areas that were free of detrital micas even though special care was taken in the selection of thin sections areas so as to include the finest matrix material. Some large crystals are visible, but for most cases they are packets composed of no more than 50 layers (Figure 5B). SAED patterns generally are composites of patterns of two $10 \AA$ clay minerals, one corresponding to poorlyordered I/S and one to well-ordered detrital mica; a (001)-sequence of reflections from chlorite is also often present (Figure 5C). The $\mathrm{c}^{*}$ axes of all such composite patterns are approximately parallel, as consistent with sequences of packets having parallel or subparallel (001) planes, and thus comprising thick stacks. Non-
(001) reflections were usually observed from SAED patterns that defined either $\mathrm{c}^{*}-\mathrm{a}^{*}$ or $\mathrm{c}^{*}-\mathrm{b}^{*}$ planes (or pseudohexagonal equivalents) of well-defined single crystals of a two layer polytype of detrital mica. However, even though areas containing only authigenic clay minerals were infrequently observed, they yielded SAED patterns with non- $(001)$ reflections occurring only as continuous streaks parallel to $\mathrm{c}^{*}$, characteristic of a $1 \mathrm{M}_{\mathrm{d}}$ polytype (Figure 5D). Such patterns show both h0l and and 0kl lines of poorly-defined, non-periodic reflections as consistent with random, turbostratic stacking. As noted above, identification of clay minerals as detrital mica or mixed-layered I/S was confirmed by AEM.

Most (00I) lattice fringe images of authigenic $\mathrm{I} / \mathrm{S}$ or illite, illite and smectite layers have the same appearance and cannot be differentiated because the smectite interlayers collapsed in the TEM-vacuum to the same $10 \AA$ spacing as illite. They form individual packets of layers only a few layers thick (approximately $80 \AA$ on average) and each packet has a slightly different orientation (Figure 5E). This misorientation is responsible for the elongation of curved 001 reflections normal to $\mathrm{c}^{*}$.

According to Guthrie and Veblen (1989), smectite and illite interlayers can produce different contrast and can only be differentiated in lattice fringe images obtained with very well-defined electron beam-(001) orientations and defocus conditions corresponding to $1000 \AA$ overfocus in their Philips 420 instrument. In our case, contrast differences were observed only in a relatively small proportion of lattice fringe images (Figure 6B). Where observed, they imply that both illite-like and smectite-like layers are present, but where absent, no such differentiation can be made. The light contrast for fringes of Figure 6B represents the smectite interlayer, as demonstrated in part by the continuity of such fringes with open interlayer spaces (marked by black triangles) produced by contraction due to dehydration. Over distances of only a few tens of layers, the sequence of mixed layers changes from a packet of R1 layers approximately $20 \mathrm{I} / \mathrm{S}$ units thick (adjacent to the calcite crystal) to a sequence with "R 3" (a single smectite layer between more than five illite layers) on the right side of Figure 6B. The area on the left side of Figure $6 \mathrm{~A}$ contains a large chlorite crystal with (001) subparallel to (001) layers of illite with an extended stack of subparallel packets of $\mathrm{I} / \mathrm{S}$ having either $\mathrm{R} 1$ or $\mathrm{R} \gg 3$ sequences.

ILLITE SAMPLE. Figure 7 is a lattice fringe image that is representative of the texture of the authigenic phyllosilicates in sample CG-5. The packets of $10 \AA$ layers are predominantly 5-15 layers thick, consist of straight, relatively defect-free layers in almost all cases, and are more nearly parallel to one another than the $\mathrm{I} / \mathrm{S}$ packets of lower grade samples, as much larger 
Table 1. Normalized formula data for detrital micas.

\begin{tabular}{|c|c|c|c|c|c|c|c|c|c|c|}
\hline & $\mathrm{Si}$ & ${ }^{\mathrm{IV}} \mathrm{Al}$ & $\mathrm{V}^{\mathrm{VI}} \mathrm{Al}$ & $\mathrm{Mg}$ & $\mathrm{Fe}$ & Eoct & $\mathbf{K}$ & $\mathrm{Na}$ & $\mathrm{Ca}$ & $\sin t \dagger$ \\
\hline \multicolumn{11}{|l|}{ L-1 } \\
\hline 1 & 2.94 & 1.06 & 1.74 & 0.31 & 0.06 & 2.11 & 0.87 & 0.21 & 0.03 & 1.07 \\
\hline 2 & 3.00 & 1.00 & 1.84 & 0.32 & 0.06 & 2.22 & 0.86 & 0.16 & 0.03 & 1.05 \\
\hline \multicolumn{11}{|l|}{$\mathrm{CO}-31$} \\
\hline 10 & 3.09 & 0.91 & 1.98 & 0.02 & 0.03 & 2.03 & 0.94 & 0.10 & 0.01 & 1.05 \\
\hline \multicolumn{11}{|c|}{ UG-25 } \\
\hline 4 & 3.22 & 0.78 & 1.91 & 0.12 & 0.06 & 2.09 & 0.85 & 0.10 & - & 0.95 \\
\hline 5 & 3.16 & 0.84 & 1.90 & 0.13 & 0.06 & 2.09 & 1.00 & 0.04 & - & 1.04 \\
\hline \multicolumn{11}{|l|}{ UG-17 } \\
\hline $2 \mathrm{~A}$ & 3.19 & 0.81 & 1.81 & 0.11 & 0.20 & 2.12 & 1.01 & 0.07 & - & 1.08 \\
\hline $5 \mathrm{~A}$ & 3.18 & 0.82 & 1.85 & 0.05 & 0.12 & 2.02 & 1.04 & 0.18 & 0.02 & 1.24 \\
\hline \multicolumn{11}{|l|}{ CG-47 } \\
\hline 2 & 3.15 & 0.85 & 1.98 & 0.08 & 0.06 & 2.12 & 0.81 & 0.09 & - & 0.90 \\
\hline 5 & 3.05 & 0.95 & 1.89 & 0.06 & 0.09 & 2.04 & 0.94 & 0.14 & - & 1.08 \\
\hline 8 & 3.04 & 0.96 & 1.91 & 0.17 & 0.06 & 2.14 & 0.68 & 0.15 & - & 0.83 \\
\hline 9 & 3.15 & 0.85 & 1.92 & 0.13 & 0.07 & 2.12 & 0.85 & 0.11 & - & 0.96 \\
\hline 12 & 3.20 & 0.80 & 1.86 & 0.14 & 0.06 & 2.06 & 0.86 & 0.10 & 0.01 & 0.96 \\
\hline \multicolumn{11}{|l|}{ CG-5 } \\
\hline 11 & 2.92 & 1.08 & 1.86 & 0.26 & 0.06 & 2.18 & 0.81 & 0.18 & - & 0.99 \\
\hline 13 & 2.81 & 1.19 & 1.83 & 0.22 & 0.06 & 2.11 & 0.86 & 0.29 & - & 1.15 \\
\hline 14 & 2.93 & 1.07 & 1.86 & 0.16 & 0.07 & 2.09 & 1.06 & - & - & 1.05 \\
\hline 15 & 3.09 & 0.91 & 1.71 & 0.32 & 0.12 & 2.15 & 0.82 & 0.10 & - & 0.92 \\
\hline 17 & 2.92 & 1.08 & 1.84 & 0.26 & 0.12 & 2.22 & 1.07 & - & - & 1.07 \\
\hline 15 -III & 3.16 & 0.84 & 1.94 & 0.18 & 0.05 & 2.17 & 0.80 & 0.13 & - & 0.93 \\
\hline 19 & 3.20 & 0.80 & 1.96 & 0.09 & 0.07 & 2.12 & 0.97 & 0.02 & 0.01 & 1.00 \\
\hline 21 & 3.14 & 0.86 & 2.02 & 0.03 & 0.04 & 2.09 & 1.07 & - & - & 1.07 \\
\hline $17-V$ & 3.07 & 0.93 & 2.03 & 0.09 & 0.05 & 2.17 & 0.84 & 0.06 & - & 0.90 \\
\hline 7 & 3.30 & 0.70 & 1.78 & 0.27 & 0.05 & 2.10 & 1.08 & 0.14 & - & 1.22 \\
\hline \multicolumn{11}{|c|}{ 1-2. EPMA data for large crystals of micas in CG-5 normalized to $\mathrm{O}_{10}(\mathrm{OH})_{2}$} \\
\hline & \multicolumn{2}{|r|}{1} & \multicolumn{2}{|c|}{2} & 3 & \multicolumn{2}{|c|}{4} & 5 & \multicolumn{2}{|r|}{6} \\
\hline $\mathrm{Si}$ & \multicolumn{2}{|r|}{3.073} & \multicolumn{2}{|l|}{3.060} & 3.127 & \multicolumn{2}{|c|}{3.178} & 3.051 & \multicolumn{2}{|r|}{3.103} \\
\hline${ }^{\mathrm{IV}} \mathrm{Al}$ & \multicolumn{2}{|r|}{0.927} & \multicolumn{2}{|l|}{0.940} & 0.873 & \multicolumn{2}{|c|}{0.822} & 0.949 & \multicolumn{2}{|r|}{0.897} \\
\hline${ }^{\mathrm{VI}} \mathrm{Al}$ & \multicolumn{2}{|r|}{1.947} & \multicolumn{2}{|l|}{1.906} & 1.789 & & & 1.838 & & 1.878 \\
\hline $\mathbf{M g}$ & & 0.035 & 0.040 & & 0.110 & & & 0.042 & & 0.067 \\
\hline $\mathrm{Fe}$ & & 0.069 & 0.056 & & 0.106 & & & 0.078 & & 0.065 \\
\hline Mn & & 0.005 & - & & 0.002 & & & 0.002 & & - \\
\hline Ti & & 0.007 & 0.014 & & 0.033 & & & 0.051 & & 0.016 \\
\hline $\mathrm{Cr}$ & & 0.002 & 0.003 & & 0.002 & & & 0.001 & & 0.002 \\
\hline Loct & & 2.065 & 2.019 & & 2.042 & & & 2.012 & & 2.028 \\
\hline K & & 0.718 & 0.821 & & 0.884 & & & 0.894 & & 0.845 \\
\hline $\mathrm{Na}$ & & 0.100 & 0.140 & & 0.040 & & & 0.077 & & 0.077 \\
\hline $\mathrm{Ca}$ & & 0.001 & - & & 0.005 & & & 0.001 & & - \\
\hline $\mathrm{Ba}$ & & 0.004 & 0.004 & & 0.001 & & & 0.004 & & 0.004 \\
\hline$\Sigma$ int $\dagger$ & & 0.823 & 0.965 & & 0.930 & & & 0.976 & & 0.926 \\
\hline F & & 0.021 & 0.036 & & 0.037 & & & 0.047 & & 0.070 \\
\hline
\end{tabular}

$\dagger$ int $=$ interlayer.

areas have all layers in the right orientation to give lattice fringes. SAED patterns with (001) reflections generally lack the elongation normal to $\mathrm{c}^{*}$ present in the mixed-layered samples because adjacent packets are more nearly parallel. Nevertheless, some heterogeneity in stacking sequence is evidenced by diffuseness of reflections parallel to $c^{*}$ (Figure 7 inset). The non-001 reflections of the inset SAED pattern of Figure 7 are consistent with a largely-disordered $1 \mathrm{M}_{\mathrm{d}}$ stacking se- quence, but with some local ordering indicated by illdefined discrete reflections. Even though more than 50 lattice fringe images of authigenic dioctahedral clay were obtained with focus conditions corresponding to observation of $\mathbf{V} / \mathrm{S}$ contrast differences, no differences such as those illustrated in Figure $6 \mathrm{~B}$ for the mixedlayer samples were observed. In addition, the general texture and contrast of the lattice fringe images from authigenic illite were much more like those of detrital 


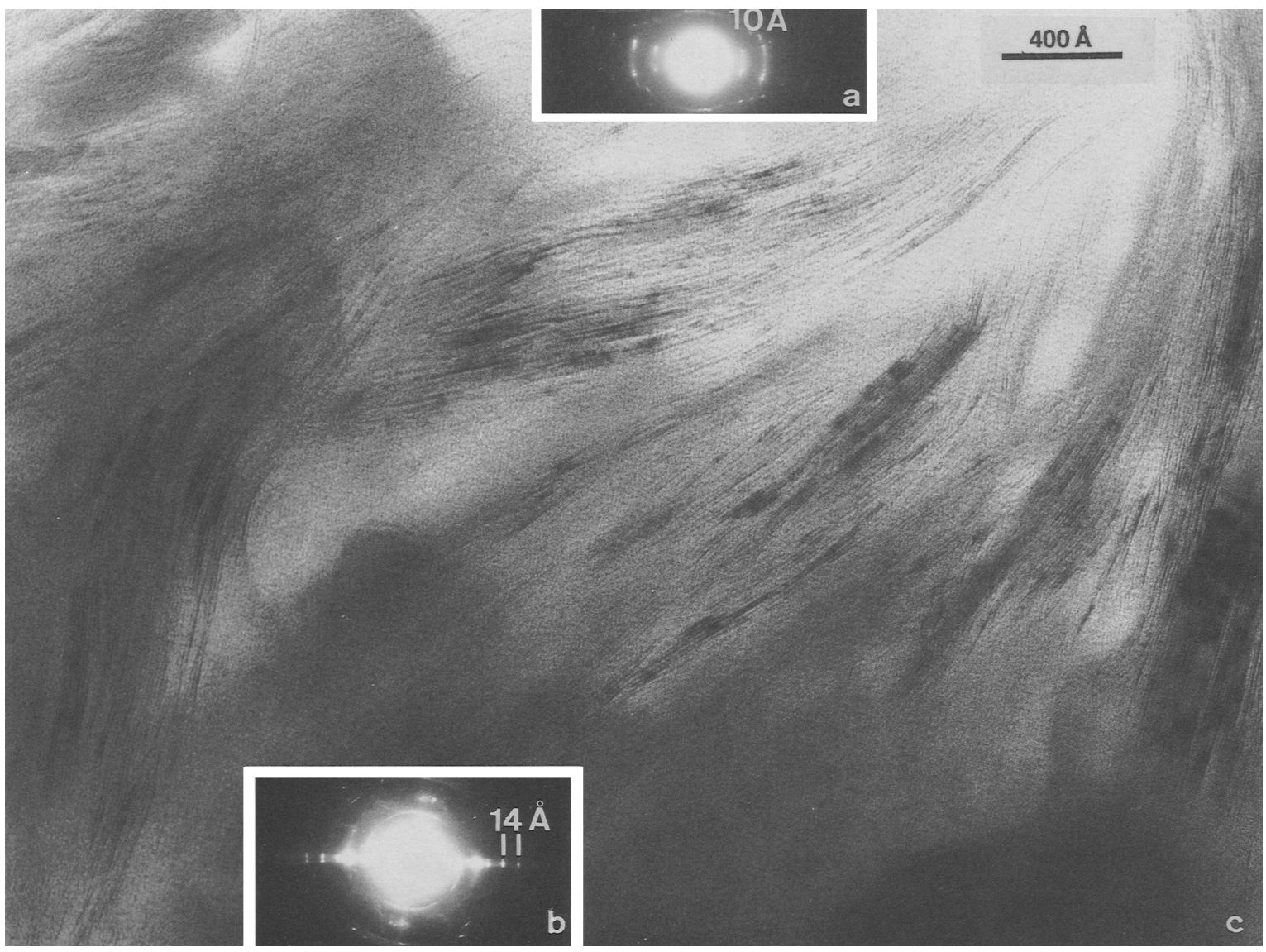

Figure 4, TEM observations for smectite of sample L-1: a) SAED pattern of contracted smectite; b) SAED pattern of noncontracted smectite; c) Lattice fringe image of non-contracted smectite, showing discontinuous, anastomosing array of layers.

micas, which were in sharp contrast to the very dissimilar appearances of I/S and detrital micas seen in lower grade samples. It was therefore more difficult to identify authigenic grains. However it was found to be possible using two criteria: 1) AEM analyses (see next section); and 2) characterization of the stacking sequence, which was predominantly $1 \mathrm{M}_{\mathrm{d}}$, as determined when SAED patterns of detrital mica-free areas were studied.

\section{TEM Observations of Particles Dispersed on Holey}

Carbon-Coated Grids

Separate clay particles dispersed on carbon-coated $\mathrm{Cu}$ grids were observed in order to determine the shapes of grains parallel to (001) and to study hk0 reflections. Such shapes may be diagnostic of certain types of clay shown to consist of euhedral crystals (Nadeau et al. 1985; Lanson and Champion 1991). We studied separates from CO-31 and CG-5, that represented the shallowest and CG-5 that represented deepest shale. Two kinds of dioctahedral phyllosilicates were observed from TEM images: 1) detrital micas with clean and homogeneous contrast and some straight boundaries, but no euhedral morphology (Figure 8A); and 2) mixed-layer $\mathrm{V} / \mathrm{S}$ or authigenic illite, with wrinkled and irregular morphology, resembling "cornflakes" (Figure 8B). Identification was confirmed in part on the basis of AEM analyses. The detrital micas gave well-defined pseudohexagonal, hk0 SAED patterns, characteristic of phyllosilicate single crystals. Illite and mixed-layered $\mathrm{I} / \mathrm{S}$ produced spotty ring-like SAED patterns. Each ring was defined by a number of individual reflections (Figure $8 \mathrm{~B}$ ). These rings consist of superimposed hk0 pseudohexagonal nets of individual coherent units, randomly rotated about $\mathrm{c}^{*}$ relative to other units. Because individual coherent crystals tend to collect in aggregates with parallel $(001)$ planes, some of the multiple reflections are due simply to overlapping crystals. In most cases, however, and in marked contrast to results for detrital micas, the multiple reflection rings are produced by individual stacks that retain the structure of the original rock sample. The SAED patterns of illite and mixed-layered I/S demonstrate that the separates consist of packets of layers. Each packet has layers, to some extent, incoherently related and randomly 

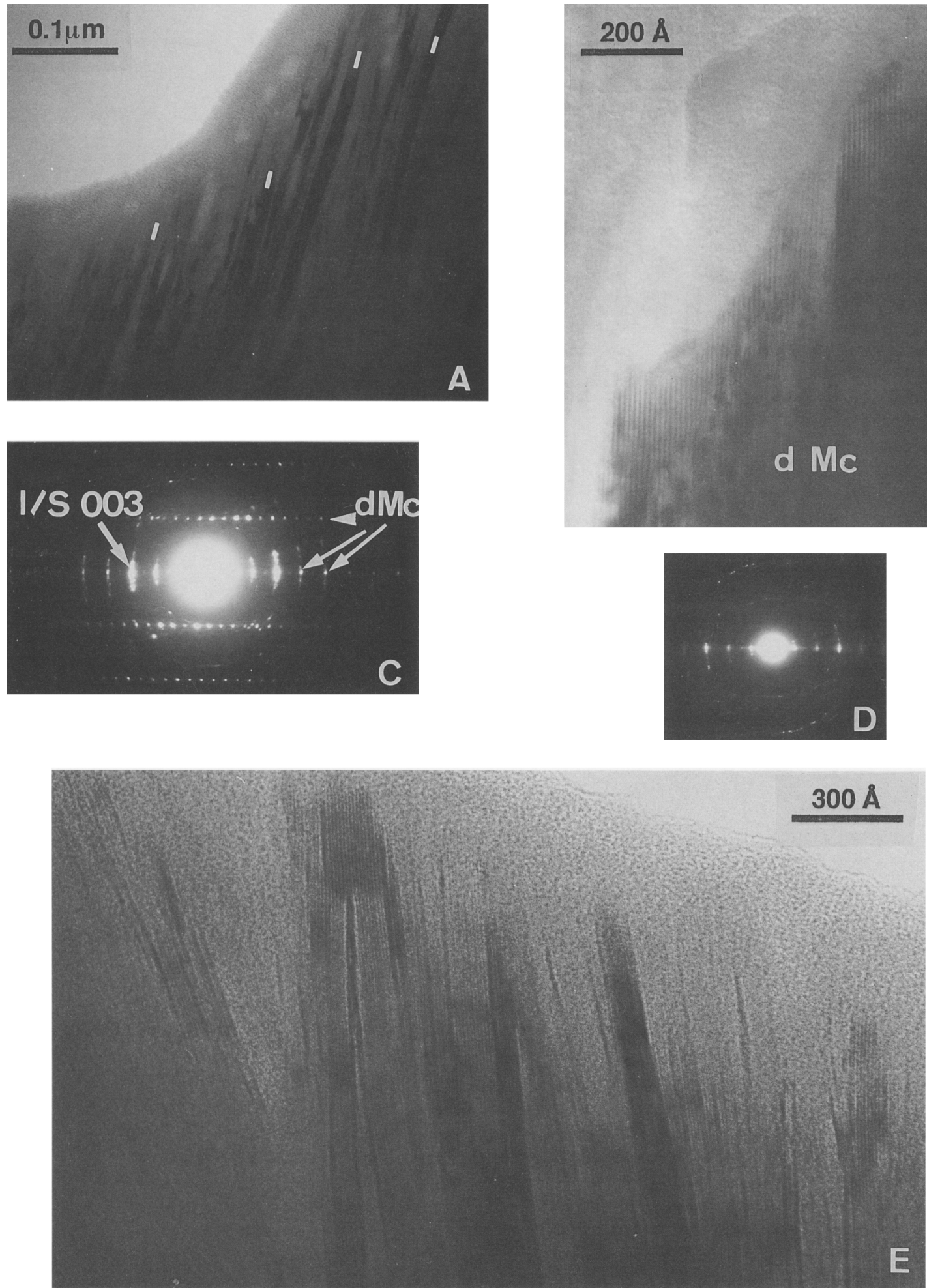

Figure 5. TEM images and SAED patterns of clay minerals in sample CO-31: A) Low magnitication TEM image representative of the texture of mixed-layer I/S. White lines represent individual detrital mica packets; B) Lattice fringe image of detrital mica crystal; C) SAED pattern representative of these found in mixed-layer samples, showing the superposition of diffraction patterns of detrital mica and mixed-layered I/S; D) SAED pattem of mixed-layer I/S with no detrital component; E) Lattice fringe image representative of mixed-layer $I / S$, showing stacks of thin individual packets typical of authigenic clay. 

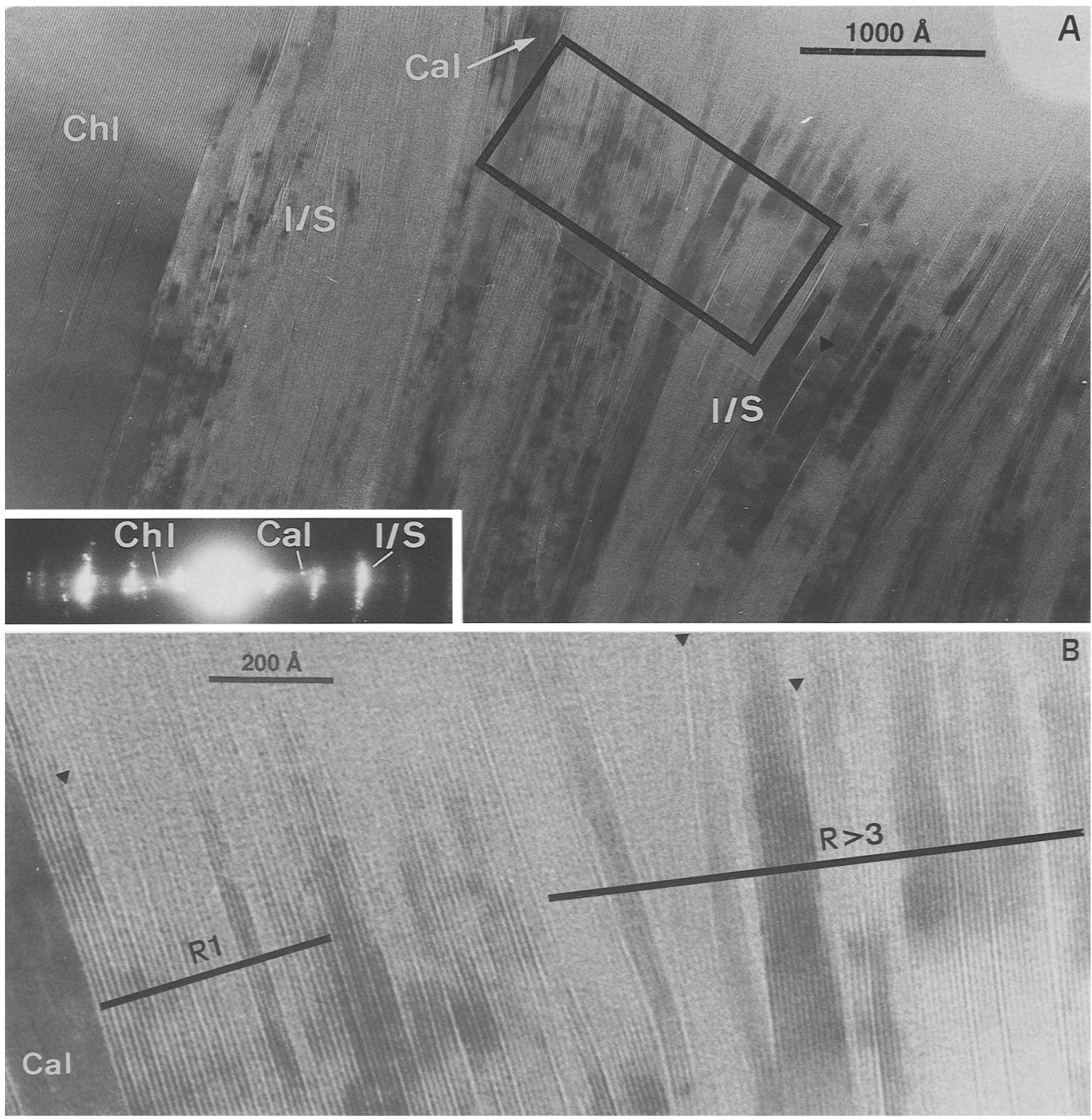

Figure 6. A) TEM image of sample UG-17 including chlorite, Rl and R>3 I/S, and calcite; B) Lattice fringe image of the area marked in Figure $6 \mathrm{~A}$ showing well-defined individual packets of $\mathrm{R} 1$ and $\mathrm{R}>3 \mathrm{I} / \mathrm{S}$.

(turbostratically) stacked. Similar results were observed by Freed and Peacor (1992) for I/S from Gulf Coast mudstones. No differences were detected in crystal outlines or SAED patterns for the two kinds of clay separates of both samples, even though they represent the lower and upper part of the shale-bearing section of the sequence.

\section{Analytical Electron Microscopy}

Microanalyses were obtained from ion-milled, unseparated samples.
Detrital MiCAS. Table 1 lists the per formula unit (pfu) compositions of detrital micas, determined by AEM, with formulae normalized to $\mathrm{O}_{10}(\mathrm{OH})_{2}$. EMPA analyses of large detrital micas from sample $\mathrm{CG}-5$ are shown for comparison (Table 1-2). The compositions determined by EMPA fall into two groups: 1) those approaching end-member muscovite, with a small phengite component $(\mathrm{Si}=3.05 \mathrm{pfu})$ and a small but significant paragonite component $(\mathrm{Na}=0.10 \mathrm{pfu})$, inferred to be of igneous or low-pressure metamorphic origin; and 2) those with a significant phengite com- 


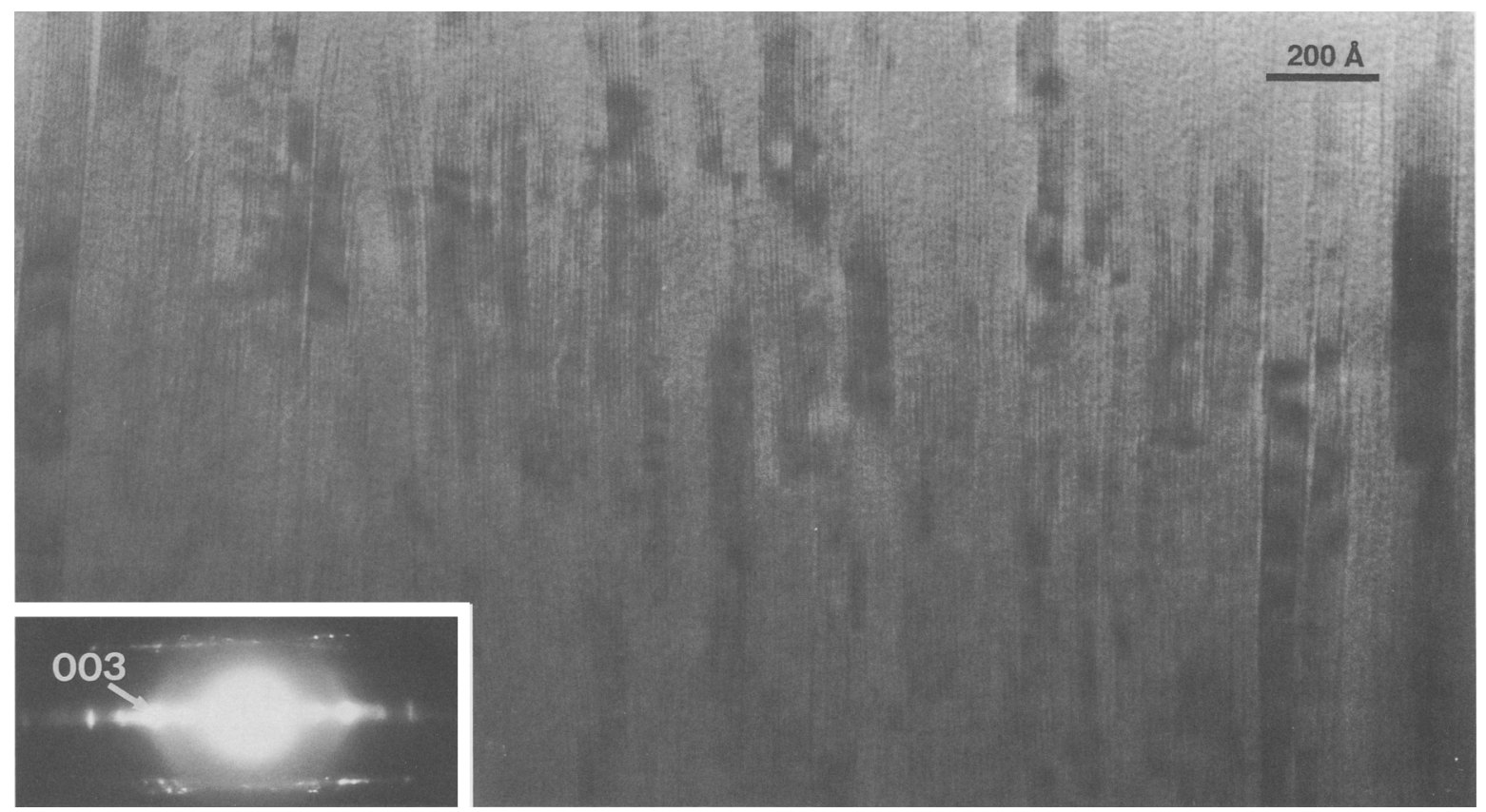

Figure 7. Lattice fringe image representative of illite-rich sample CG-5. The illite consists of individual packets comprising a thick stack typical of late authigenic illite. The inset SAED pattern displays some periodicity superimposed on non-periodic, diffuse reflections, as consistent with local order in a largely-disordered sequence.
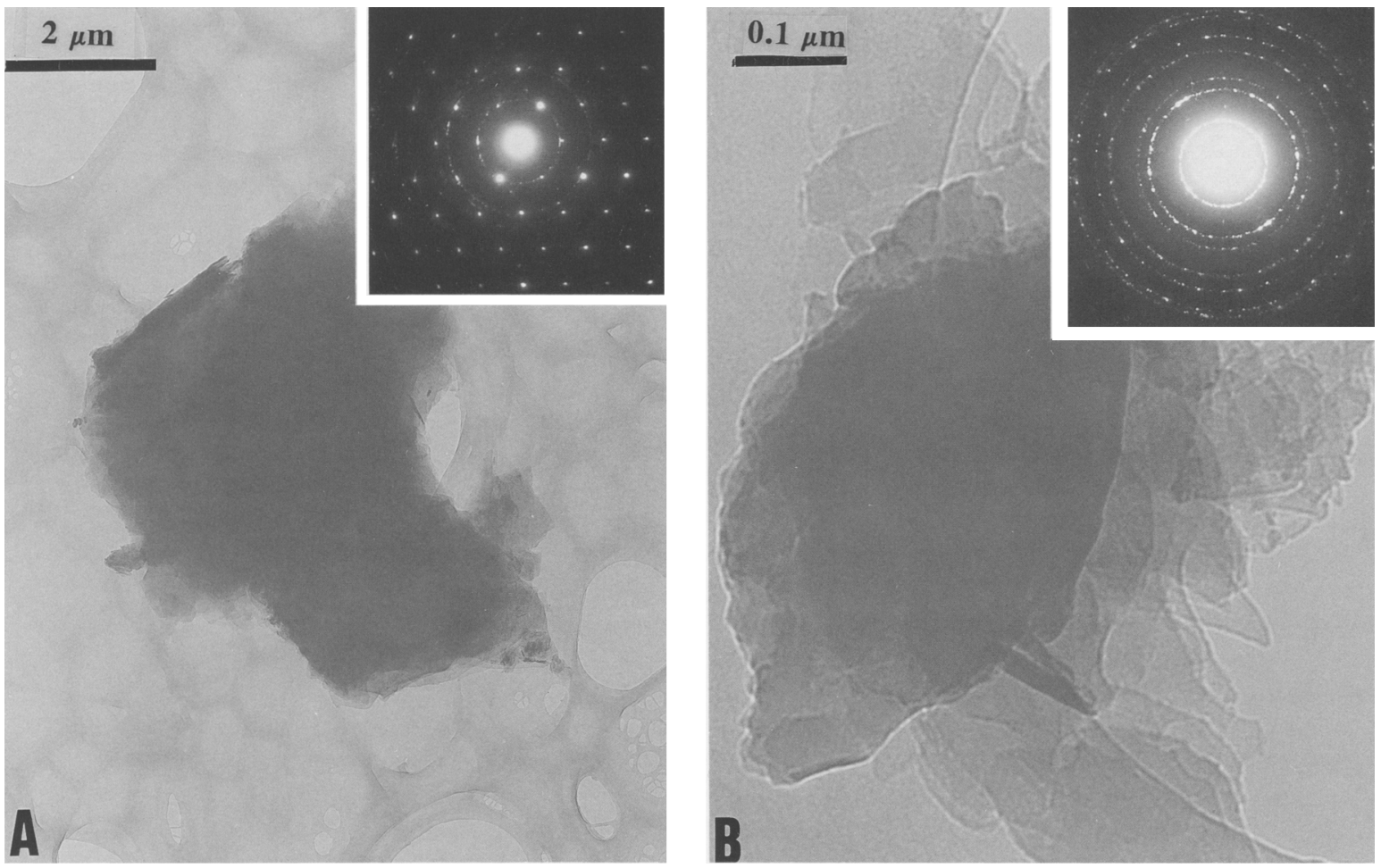

Figure 8. Image and diffraction pattern of grains from a powdered sample, oriented with (001) parallel to the surface of a C-coated copper grid: A) Single-crystal hk0 diffraction pattern of detrital mica, as consistent with coherently-related layers; B) Spotty, powder-diffraction-like SAED pattern of I/S, as consistent with a high proportion of incoherent interfaces (partial turbostratic stacking). 
Table 2. AEM data for smectites in L-1 normalized to $\mathrm{O}_{10}(\mathrm{OH})_{2}$.

\begin{tabular}{|c|c|c|c|c|c|c|c|c|c|c|c|}
\hline & $\mathrm{Si}$ & ${ }^{\mathrm{v}} \mathrm{Al}$ & $\mathrm{v}_{\mathrm{Al}}$ & $\mathbf{M g}$ & $\mathrm{Fe}$ & Eoct & K & $\mathrm{Na}$ & $\mathrm{Ca}$ & $\sin \dagger^{\dagger}$ & $\sum$ charge \\
\hline \multicolumn{12}{|c|}{ Noncontracted smectites } \\
\hline 3 & 3.55 & 0.45 & 1.37 & 0.59 & 0.23 & 2.19 & 0.36 & 0.07 & 0.14 & 0.57 & 0.71 \\
\hline 4 & 3.64 & 0.36 & 1.26 & 0.68 & 0.23 & 2.17 & 0.35 & - & 0.26 & 0.61 & 0.87 \\
\hline 5 & 3.64 & 0.36 & 1.29 & 0.70 & 0.23 & 2.22 & 0.27 & 0.08 & 0.15 & 0.50 & 0.65 \\
\hline 6 & 3.57 & 0.43 & 1.39 & 0.52 & 0.24 & 2.15 & 0.40 & 0.07 & 0.14 & 0.61 & 0.75 \\
\hline 7 & 3.74 & 0.26 & 1.33 & 0.59 & 0.20 & 2.12 & 0.28 & 0.11 & 0.17 & 0.55 & 0.72 \\
\hline 9 & 3.54 & 0.46 & 1.53 & 0.43 & 0.18 & 2.14 & 0.36 & 0.10 & 0.18 & 0.58 & 0.76 \\
\hline 16 & 3.73 & 0.27 & 1.36 & 0.46 & 0.23 & 2.05 & 0.32 & 0.07 & 0.19 & 0.62 & 0.81 \\
\hline Average & 3.63 & 0.37 & 1.36 & 0.57 & 0.22 & 2.15 & 0.33 & 0.07 & 0.18 & 0.58 & 0.75 \\
\hline \multicolumn{12}{|c|}{ Contracted smectites } \\
\hline 10 & 3.48 & 0.52 & 1.61 & 0.29 & 0.19 & 2.10 & 0.65 & 0.06 & 0.09 & 0.80 & 0.89 \\
\hline 11 & 3.65 & 0.35 & 1.47 & 0.36 & 0.24 & 2.07 & 0.54 & 0.03 & 0.12 & 0.69 & 0.81 \\
\hline 12 & 3.69 & 0.31 & 1.34 & 0.44 & 0.29 & 2.07 & 0.49 & 0.10 & 0.16 & 0.75 & 0.91 \\
\hline 13 & 3.75 & 0.25 & 1.38 & 0.43 & 0.26 & 2.07 & 0.47 & - & 0.15 & 0.62 & 0.77 \\
\hline 14 & 3.72 & 0.28 & 1.32 & 0.46 & 0.28 & 2.06 & 0.51 & 0.09 & 0.17 & 0.77 & 0.94 \\
\hline 15 & 3.72 & 0.28 & 1.35 & 0.42 & 0.29 & 2.06 & 0.53 & 0.07 & 0.14 & 0.74 & 0.88 \\
\hline Average & 3.67 & 0.33 & 1.41 & 0.40 & 0.26 & 2.07 & 0.53 & 0.06 & 0.14 & 0.73 & 0.87 \\
\hline
\end{tabular}

$\dagger$ int $=$ interlayer.

ponent $(\mathrm{Si}=3.15 \mathrm{pfu})$ with very little $\mathrm{Na}(<0.05 \mathrm{pfu})$, probably of medium-pressure and low-temperature metamorphic origin.

Many of the AEM-determined formulae are within those groups, but some analyses are between them. All analyses clearly correspond to mature micas of relatively high-temperature origin (net negative charges approach the ideal value of 1) and are clearly very different to authigenic clays in that regard. The differences between average EMPA and AEM results are within the standard error of the AEM values. The $K$ contents, when determined using the short $30 \mathrm{~s}$ count times described in the "Methods" section, approach the ideal value for muscovite and phengite. Although standard errors for $\mathbf{K}$ contents are greater than for other elements determined with the longer counting time, the data are not significantly affected by the volatilization problem. This is consistent with our general experience with AEM analyses of $\mathrm{K}$-rich clay minerals, with $\mathrm{K}$ diffusion being less significant for more mature crystals. The comparison of EMPA and AEM data, although obtained for different crystals, still serves as a guide for evaluating the precision of the AEM analyses of detrital micas and by analogy, of those of authigenic clay minerals described below.

The samples corresponding to the lower part of the sequence (CG-5 and CG-47) contain detrital micas with compositions corresponding to both of the groups described above. Only micas corresponding to nearly ideal muscovite were observed, from shale samples corresponding to the shallower part of the section (L-1 and $\mathrm{CO}-31$ ).

SMECTITE. Analyses of the two different kinds of smectite from sample L-1 (collapsed $10 \AA$ layers, and uncollapsed layers) described above are given in Table 2 under the subheadings "contracted" and "non-contracted" smectite. The compositions of the TOT (Tetrahedral-Octahedral-Tetrahedral Layer) packets are very similar with no systematic differences. Silica contents range from 3.50 to 3.75 per formula unit (pfu), $\mathrm{Mg}$ contents from 0.3 to $0.7 \mathrm{pfu}$ with slightly higher values for the non-contracted smectites, and $\mathrm{Fe}$ contents from 0.2 to $0.3 \mathrm{pfu}$. The most striking difference is in the $K$ contents, which clearly define different ranges for contracted $(0.5-0.65)$ and non-contracted $(0.25-0.40)$ smectite. The other interlayer cations are present in similar proportions from both types of smectites. The $\mathrm{Na}$ content is low and the $\mathrm{Ca}$ content is lower than that of $\mathrm{K}$ in all analyses but slightly higher on an absolute basis for the non-contracted smectites.

AUTHIGENIC MIXED-LAYERED I/S AND ILLITE. The compositions of mixed-layered $\mathrm{I} / \mathrm{S}$ and illite are given in Table 3. The principal interlayer cation is $K$ for almost all cases, but for some restricted areas of samples CO-31, UG-17 and CG-5 there are parallel intergrowths of $\mathrm{Na}$-rich and $\mathrm{K}$-rich clays. The tetrahedral and octahedral cation contents are extremely heterogeneous. The differences between grains are within standard errors of analysis and are similar to the differences between average values for different samples. The differences between $\mathrm{Mg}$ and Fe contents are small and apparently not systematically related to either the proportion of illite layers or to depth of sample within the sediment sequence. Most values range from $0.1-$ $0.25 \mathrm{pfu}$ for $\mathrm{Mg}$ and $0.05-0.10 \mathrm{pfu}$ for Fe, which are much lower values than those for smectite, which occur in shallower sediments. The tetrahedral $\mathrm{Si}$ and $\mathrm{Al}$ contents show considerable variation, but the average $\mathrm{Si}$ content of approximately $3.2 \mathrm{Si}$ pfu is typical of 
Table 3. AEM data for I/S mixed-layers normalized to $\mathrm{O}_{10}(\mathrm{OH})_{2}$.

\begin{tabular}{|c|c|c|c|c|c|c|c|c|c|c|}
\hline & $\mathrm{Si}$ & ${ }^{n} \mathrm{Al}$ & $\mathrm{v}_{\mathbf{A}} \mathbf{A} \mid$ & $\mathrm{Mg}$ & $\mathrm{Fe}$ & Loct & $\mathrm{K}$ & $\mathrm{Na}$ & $\mathrm{Ca}$ & Eint \\
\hline \multicolumn{11}{|l|}{$\mathrm{CO}-31$} \\
\hline 1 & 3.31 & 0.69 & 1.91 & 0.16 & 0.08 & 2.15 & 0.50 & - & 0.03 & - \\
\hline 2 & 3.30 & 0.70 & 1.94 & 0.16 & 0.08 & 2.18 & 0.40 & - & - & - \\
\hline 3 & 3.39 & 0.41 & 1.85 & 0.20 & 0.08 & 2.13 & 0.35 & 0.03 & - & 0.38 \\
\hline 6 & 3.53 & 0.47 & 1.89 & 0.11 & 0.19 & 2.19 & 0.39 & - & - & 0.39 \\
\hline 7 & 3.78 & 0.22 & 1.94 & 0.04 & 0.07 & 2.05 & 0.41 & - & - & 0.41 \\
\hline 11 & 3.82 & 0.18 & 1.87 & 0.07 & 0.07 & 2.01 & 0.27 & 0.09 & - & 0.36 \\
\hline 14 & 3.26 & 0.74 & 1.91 & 0.22 & 0.10 & 2.23 & 0.47 & - & - & 0.47 \\
\hline 16 & 3.25 & 0.75 & 2.00 & 0.11 & 0.09 & 2.20 & 0.44 & 0.04 & - & 0.48 \\
\hline 17 & 3.26 & 0.74 & 2.01 & 0.12 & 0.09 & 2.22 & 0.45 & - & - & 0.45 \\
\hline \multicolumn{11}{|c|}{ UG-25 } \\
\hline 3 & 3.25 & 0.75 & 2.01 & 0.11 & 0.04 & 2.16 & 0.59 & 0.08 & 0.01 & 0.68 \\
\hline 8 & 3.39 & 0.61 & 1.95 & 0.18 & 0.03 & 2.16 & 0.45 & 0.09 & - & 0.54 \\
\hline 9 & 3.50 & 0.50 & 1.97 & 0.14 & 0.05 & 2.16 & 0.45 & - & - & 0.45 \\
\hline 10 & 3.59 & 0.41 & 1.86 & 0.17 & 0.08 & 2.11 & 0.49 & 0.06 & 一 & 0.55 \\
\hline \multicolumn{11}{|l|}{ UG-17 } \\
\hline 3 & 3.32 & 0.68 & 1.76 & 0.30 & 0.11 & 2.17 & 0.64 & 0.12 & - & 0.76 \\
\hline 4 & 3.16 & 0.84 & 1.80 & 0.23 & 0.29 & 2.32 & 0.34 & 0.17 & 0.02 & 0.53 \\
\hline 5 & 3.16 & 0.84 & 1.91 & 0.22 & 0.10 & 2.23 & 0.40 & 0.18 & 0.02 & 0.60 \\
\hline 6 & 2.98 & 1.02 & 1.93 & 0.25 & 0.11 & 2.29 & 0.44 & 0.12 & 0.01 & 0.57 \\
\hline 7 & 2.99 & 1.01 & 1.91 & 0.27 & 0.10 & 2.28 & 0.49 & 0.08 & - & 0.57 \\
\hline 2-III & 3.19 & 0.81 & 1.94 & 0.12 & 0.07 & 2.13 & 0.70 & 0.10 & - & 0.80 \\
\hline \multicolumn{11}{|l|}{ CG-47 } \\
\hline 3 & 3.21 & 0.79 & 1.91 & 0.14 & 0.06 & 2.11 & 0.50 & 0.18 & 0.01 & 0.69 \\
\hline 4 & 3.11 & 0.89 & 1.87 & 0.12 & 0.25 & 2.24 & 0.50 & 0.09 & 0.01 & 0.60 \\
\hline 6 & 3.24 & 0.76 & 2.06 & 0.10 & 0.04 & 2.20 & 0.28 & 0.12 & - & 0.40 \\
\hline 7 & 3.22 & 0.78 & 2.00 & 0.11 & 0.04 & 2.15 & 0.57 & 0.07 & - & 0.64 \\
\hline \multicolumn{11}{|l|}{ CG-5 } \\
\hline $1 \mathrm{~s}$ & 3.24 & 0.76 & 1.92 & 0.09 & 0.06 & 2.07 & 0.70 & 0.09 & - & 0.79 \\
\hline $2 s$ & 3.26 & 0.74 & 1.96 & 0.08 & 0.05 & 2.09 & 0.61 & 0.08 & - & 0.68 \\
\hline $3 \mathrm{~s}$ & 3.50 & 0.50 & 1.88 & 0.08 & 0.07 & 2.03 & 0.70 & - & - & 0.70 \\
\hline 3 & 3.25 & 0.75 & 1.69 & 0.37 & 0.14 & 2.20 & 0.68 & 0.21 & - & 0.89 \\
\hline 4 & 3.32 & 0.68 & 1.75 & 0.31 & 0.11 & 2.17 & 0.57 & 0.24 & - & 0.81 \\
\hline 6 & 3.24 & 0.76 & 1.78 & 0.33 & 0.06 & 2.17 & 0.67 & 0.13 & - & 0.80 \\
\hline 8 & 3.27 & 0.73 & 1.87 & 0.23 & 0.02 & 2.12 & 0.61 & 0.21 & - & 0.82 \\
\hline 12 & 3.23 & 0.77 & 1.93 & 0.23 & 0.08 & 2.24 & 0.57 & 0.13 & - & 0.70 \\
\hline 16 & 3.22 & 0.78 & 1.89 & 0.26 & 0.10 & 2.25 & 0.65 & 0.11 & 0.02 & 0.78 \\
\hline $13 \mathrm{~N}$ & 3.32 & 0.68 & 1.91 & 0.09 & 0.16 & 2.16 & 0.59 & - & 0.04 & 0.63 \\
\hline 14-IV & 3.49 & 0.51 & 1.66 & 0.39 & 0.15 & 2.20 & 0.73 & 0.08 & - & 0.81 \\
\hline 18 & 3.24 & 0.76 & 1.86 & 0.20 & 0.18 & 2.24 & 0.74 & - & - & 0.74 \\
\hline \multicolumn{11}{|c|}{ NA-rich area } \\
\hline \multicolumn{11}{|c|}{ UG-17 } \\
\hline 2 & 3.16 & 0.84 & 2.09 & 0.13 & 0.02 & 2.24 & 0.04 & 0.52 & 0.02 & 0.58 \\
\hline 4-III & 3.21 & 0.79 & 2.15 & 0.07 & 0.02 & 2.24 & 0.04 & 0.21 & - & 0.24 \\
\hline 5-III & 3.22 & 0.78 & 2.15 & 0.07 & 0.02 & 2.24 & 0.05 & 0.36 & - & 0.41 \\
\hline
\end{tabular}

$\dagger$ int $=$ interlayer.

illite. More importantly, there is no systematic variation of Si content with sample depth or with proportion of illite layer. The Si content of R1 I/S is approximately the same as that of illite. Ca is undetectable or is present in amounts within standard errors of analysis, whereas $\mathrm{Na}$ contents vary from 0.0 to 0.25 for $\mathrm{K}$-rich clays. However, this range may actually be smaller, considering the relatively large standard error for EDS analyses of $\mathrm{Na}$, especially in the presence of $\mathrm{Mg}, \mathrm{Al}$ and $\mathrm{Si}$. The $\mathrm{K}$ content of illite varies from 0.57 to 0.70 for sample CG-5, but is highly variable for all mixed-layered US, with the maximum value corresponding to that for pure illite. Mean values for each sample are given in Table 4. These are consistent with the kind of illite material for which they were obtained, ranging from 0.40 to 0.52 for the mixed-layer samples and equal to 0.63 for the illite sample. Figure 9 is a plot of the average interlayer content as a function of depth. There is a clearly-defined trend of increasing interlayer cation content with increasing depth. The general trend is in agreement with previous XRD interpretations (Aróstegui et al. 1991). They pre- 
Table 4. AEM data (mean values) for $\mathrm{I} / \mathrm{S}$ mixed-layers normalized to $\mathrm{O}_{10}(\mathrm{OH})_{2}$.

\begin{tabular}{|c|c|c|c|c|c|c|c|c|c|c|c|}
\hline & Depth $(m)$ & $\mathrm{Si}$ & ${ }^{i N} \mathrm{Al}$ & $\mathrm{v}_{\mathrm{A}}^{\mathrm{AI}}$ & $\mathrm{Mg}$ & $\mathrm{Fe}$ & Eoct & $\mathbf{K}$ & $\mathrm{Na}$ & $\mathrm{Ca}$ & Eintf \\
\hline $\mathrm{CO}-31$ & 1430 & 3.45 & 0.55 & 1.94 & 0.14 & 0.09 & 2.17 & 0.40 & 0.02 & - & 0.42 \\
\hline UG-25 & 1880 & 3.39 & 0.61 & 1.96 & 0.15 & 0.05 & 2.16 & 0.50 & 0.05 & - & 0.55 \\
\hline UG-17 & 2905 & 3.13 & 0.87 & 1.88 & 0.23 & 0.13 & 2.24 & 0.50 & 0.13 & - & 0.63 \\
\hline CG-47 & 3110 & 3.20 & 0.80 & 1.96 & 0.12 & 0.06 & 2.14 & 0.52 & 0.12 & - & 0.64 \\
\hline CG-5 & 8010 & 3.31 & 0.69 & 1.83 & 0.23 & 0.10 & 2.16 & 0.65 & 0.12 & - & 0.77 \\
\hline
\end{tabular}

$\dagger$ int $=$ interlayer.

dicted a progressive evolution from R1 I/S through R3 $\mathrm{I} / \mathrm{S}$ to illite. These data therefore imply that the interlayer cation content of R1 I/S is definitively lower than that of illite. Nevertheless, Figure 9 shows that there is no relation between $\mathrm{K}$ content and $\mathrm{Si} / \mathrm{Al}$ ratio, that is, the interlayer cation population increases with the proportion of illite but is not accompanied by an increase in $\mathrm{Si} / \mathrm{Al}$ ratio.

NA-RICH/K-RICH MIXED-LAYER INTERGROWTHS. Parallel intergrowths of two types of clays producing darker and lighter contrast in low magnification TEM images were recognized from small areas of two mixed-layered I/S samples. When analyzed, the darker contrast was found to correspond to $\mathrm{K}$-rich mixed-layered $\mathrm{I} / \mathrm{S}$ or illite as described in the previous section and the lighter contrast to Na-rich material, denoted in Table 3 as Na-rich areas. Such material is tentatively identified as mixed-layered paragonite/smectite on the basis of the analyses, diffraction patterns and morphology from TEM images. According to the relations between phengite and paragonite within metamorphic rocks observed by Shau et al. (1991), the Na-rich material has lower $\mathrm{Mg}$ and $\mathrm{Fe}$ contents than the $\mathrm{K}$-rich material.

CHLORITE. Chlorite is not very abundant within the sediments of the Basque-Cantabrian basin, but was detected in almost all samples by XRD (Aróstegui et al.
1991). Both authigenic (Figure 6A and 11A) and detrital (Figure 10B) crystals were identified by TEM, but differentiation was difficult. Some AEM analyses are listed in Table 5 with the origin indicated where possible. In accordance with the presence of some 10 $\AA$ lattice fringes or obvious signs of alteration, all the chlorite recognized as detrital provided analyses showing the chemical characteristics described by Shau et al. (1991) as representative of contamination by corrensite or smectite interlayers, high $\mathrm{Si}$ content, ${ }^{[\mathrm{VI}]} \mathrm{Al}$ content much higher than ${ }^{\left[{ }^{I V}\right]} \mathrm{Al}$ content, and total octahedral population much lower than 6 cations pfu. In marked contrast, chlorite identified as authigenic gave nearly ideal chlorite formulae. Authigenic chlorite is significantly more Fe-rich than detrital chlorite with $\mathrm{F} / \mathrm{FM}(\mathrm{Fe} / \mathrm{Fe}+\mathrm{Mg}$ ) ratios ranging from 0.55 to 0.84 .

\section{DISCUSSION}

\section{Detrital Mica}

Both SEM and TEM images show that the BasqueCantabrian shales are composed of an unusually high proportion of phyllosilicates. Mica is dominant over the full range of grain sizes, including the fine-grained matrix in which grains can only be resolved by TEM. Nevertheless, fine-grained detrital mica occurring within the matrix is readily characterized and differentiated from authigenic illite by: 1) absence of dis-
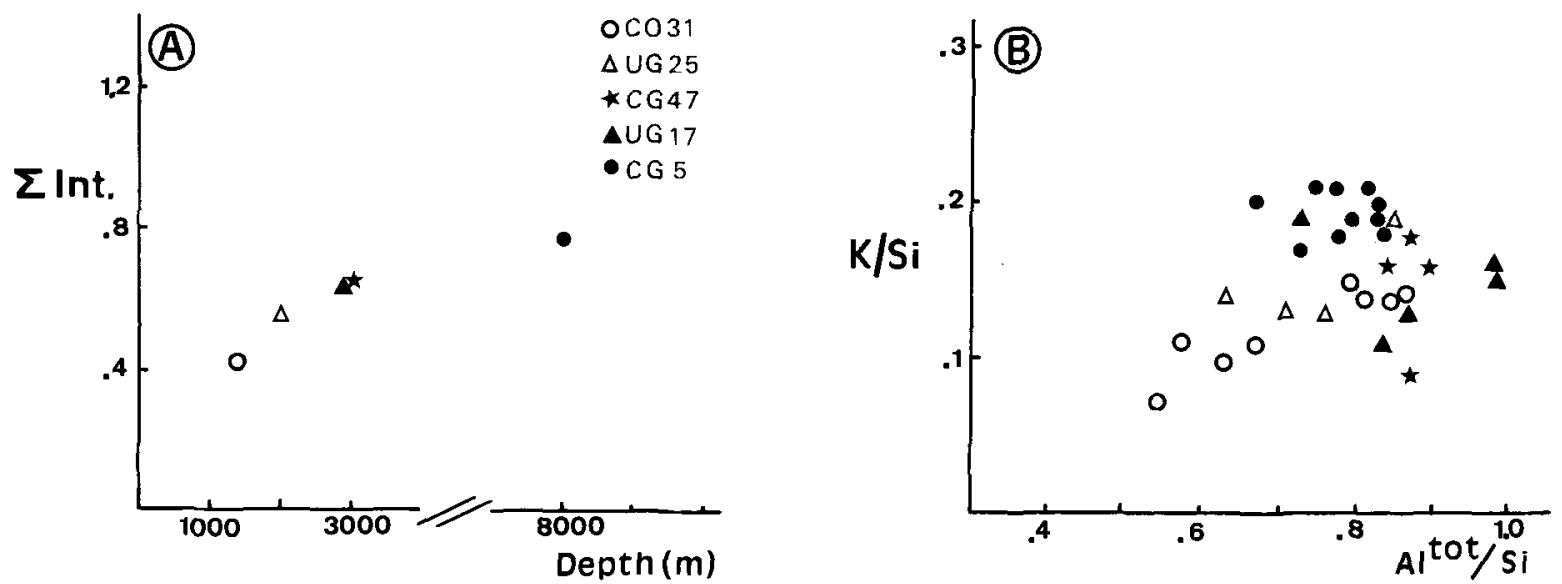

Figure 9. A) Plot of mean interlayer cation contents vs. depth, illustrating increase of cation content relative to the limiting value of 1 for mature mica; $\mathrm{B}$ ) $\mathrm{K} / \mathrm{Si}$ versus $\mathrm{Al} / \mathrm{Si}$ ratios for the microanalyses included in Table 3 . 

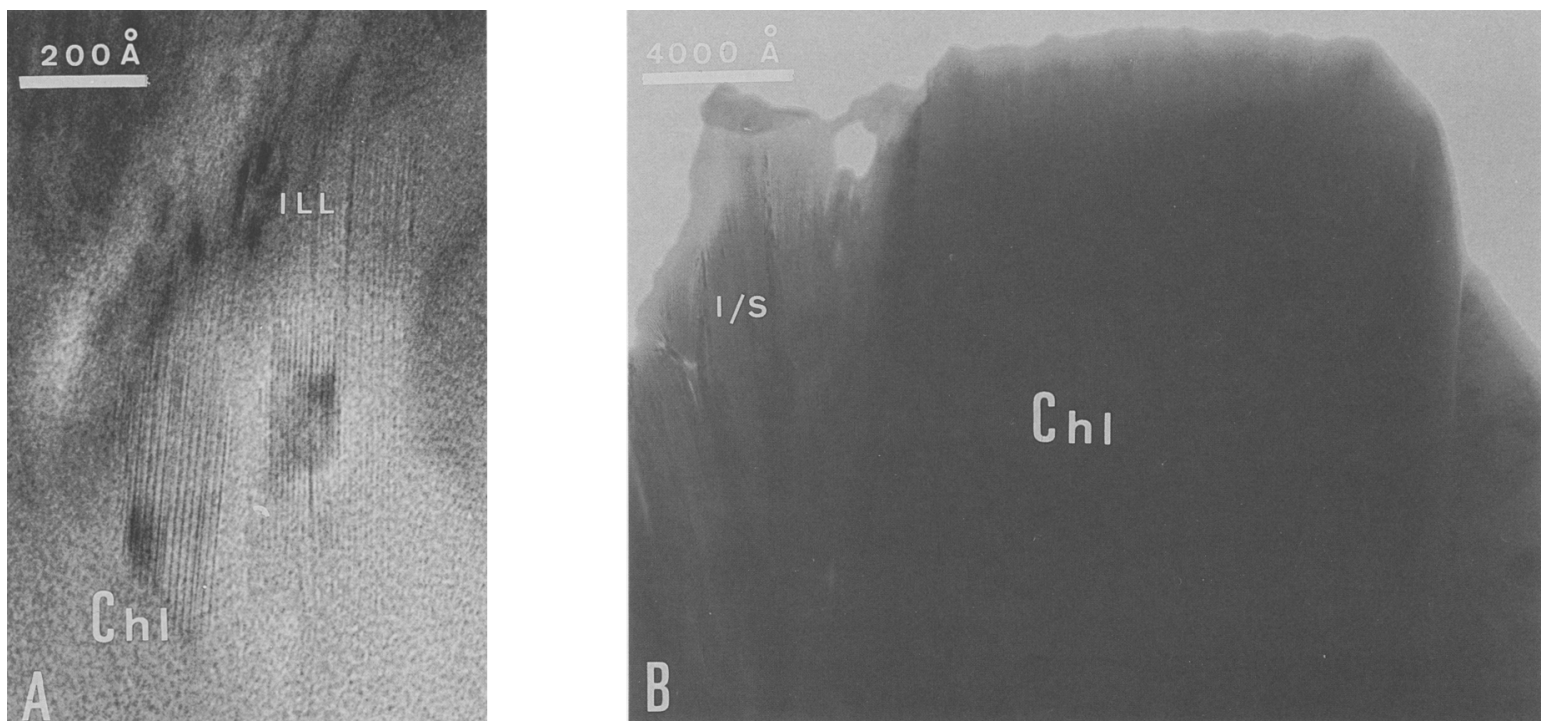

Figure 10. Representative TEM images of chlorite: A) Thin packet of authigenic chlorite in contact with authigenic illite; B) Large grain of detrital chlorite, typically $>1 \mu \mathrm{m}$ thick.

locations (layer terminations); 2) presence of two-layer (presumably $2 \mathrm{M}_{1}$ ) polytypism; 3) an interlayer cation content close to $1 \mathrm{pfu}$; and 4) a $\mathrm{Si} / \mathrm{Al}$ ratio typical of muscovite or muscovite with a low phengite component. The compositions of the fine-grained detrital micas determined by AEM are generally similar to the two kinds of composition determined by EMPA for the largest detrital grains, which can be recognized by optical microscopy or, in some cases, from hand sample. These mica grains, sometimes consisting of no more than 20 layers, must result from mechanical weathering of two classes of source rocks. Various geological units containing metapelites and igneous rocks have been described as the origin of the sediments deposited within the Basque-Cantabrian basin
(Amiot et al. 1982). The two kinds of micas recog nized as large detrital grains from the deepest sample (CG-5) were also detected from the clay fraction of the deeper shale samples. Changes in the detrital input of the shallower part of the shale sequence may have occurred, but the scarcity of detrital mica analyses prevents our stating this with certainty.

Few signs of chemical alteration or textural change were detected for the detrital micas. They played a predominantly passive role during deposition and diagenesis and acted as a neutral material around which detrital clay minerals, presumably dominated by smectite, reacted during diagenesis. On the basis of BSE images, Crowley (1991) concluded that dioctahedral mica was stable during diagenesis of sandstones from

Table 5. AEM data for chlorites normalized to $\mathrm{O}_{10}(\mathrm{HO})_{2}$.

\begin{tabular}{|c|c|c|c|c|c|c|c|c|c|c|}
\hline & & $\mathrm{Si}$ & ${ }^{\mathrm{IV}} \mathrm{Al}$ & $\mathrm{v}^{\mathrm{v}_{\mathrm{Al}}}$ & $\mathrm{Fe}$ & $\mathrm{Mg}$ & Eoct & $\mathrm{K}$ & $\mathrm{Na}$ & $\mathrm{Ca}$ \\
\hline \multicolumn{11}{|l|}{$\mathrm{CO}-31$} \\
\hline & 1 & 2.68 & 1.32 & 1.46 & 2.47 & 1.99 & 5.92 & 0.05 & - & - \\
\hline & 2 & 2.73 & 1.27 & 1.44 & 2.62 & 1.84 & 5.90 & 0.04 & - & - \\
\hline A & 12 & 2.58 & 1.42 & 1.21 & 3.20 & 1.68 & 6.09 & - & - & 0.02 \\
\hline \multicolumn{11}{|l|}{ UG-17 } \\
\hline & 1 & 2.67 & 1.33 & 1.79 & 2.96 & 0.95 & 5.70 & 0.04 & 0.10 & - \\
\hline & 2 & 2.67 & 1.33 & 1.80 & 2.96 & 1.00 & 5.76 & 0.04 & - & - \\
\hline $\mathrm{D}^{\dagger}$ & 4 & 3.18 & 0.82 & 2.52 & 1.94 & 0.57 & 5.03 & 0.05 & 0.21 & - \\
\hline & 6 & 2.67 & 1.33 & 1.87 & 3.23 & 0.60 & 5.70 & 0.03 & - & 0.02 \\
\hline \multicolumn{11}{|l|}{ CG-5 } \\
\hline $\mathrm{D}_{\dagger}^{\dagger}$ & 1 & 3.20 & 0.80 & 2.76 & 0.83 & 1.02 & 4.61 & 0.05 & 0.68 & 0.06 \\
\hline A & 2 & 2.56 & 1.44 & 1.53 & 3.21 & 1.22 & 5.96 & - & - & - \\
\hline
\end{tabular}

$\mathrm{D}=$ Detrital

A $=$ Authigenic.

$\dagger$ Samples with evident signs of alteration. 
the Great Limestone Cyclothem at Durham (UK). That observation is in agreement with the frequent identification of chemically non-equilibrated micas from low grade (López Munguira et al. 1991) or even medium grade rocks (Massone and Schreyer, 1987). Indeed, Jiang et al. (1990) concluded that illite and indirectly, smectite are metastable phases relative to true micas, which are the thermodynamically stable phases. Smectite, illite, and mixed-layered I/S were inferred to be path-dependent phases evolving toward stable micas during diagenesis. A result of such a relationship is that detrital micas should be largely unchanged during diagenesis, as observed.

\section{Unusual K Content of Smectite in Marls}

The composition of smectite in the marl is unusual and of interest for three reasons.

1) The dominant interlayer cation is $K$, rather than the $\mathrm{Na}$ or $\mathrm{Ca}$, which is normally found in non-marine smectites. $\mathrm{K}$ is normally associated with illite as a reaction product of smectite. High smectite $\mathrm{K}$ contents are generally viewed as being exceptional. Nevertheless, several recent AEM studies of smectite from marine sediments have found similarly high $K$ interlayer contents, including: i) smectite altered from volcanic glass from the Barbados accretionary wedge (Buatier et al. 1992); ii) smectite-rich I/S from Gulf Coast sediments (Freed and Peacor 1992); and iii) recent marine sediments from both the Atlantic and Indian Oceans (Dickens personal communication, 1994). Rather than being unusual, high $\mathrm{K}$ contents may actually be common for sediments undergoing diagenesis. One possible source of the $\mathrm{K}$ is through cation exchange of originally $\mathrm{Na}$ - or Ca-rich smectite (Freed and Peacor 1992), where the $K$ would be derived from coexisting solids or introduced through circulating fluids.

2) The interlayer charge and especially the K content are exceptionally high. They approach values normally associated with illite rather than smectite (Tables 2 and 3). The accuracy of the values is supported by: i) the smectites contain non-contracted layers with slightly lower net negative charges and lower interlayer cation contents than those with contracted layers; ii) the agreement of equivalent analyses of $I / S$, illite and micas with normal expected values; and iii) the net negative charges independently calculated on the basis of octahedral and tetrahedral cation contents approximately agree with the interlayer cation charges. The XRD studies of the relationship between the nature of the interlayer cation and swelling behavior of smectite have shown that interlayer divalent and smaller radius cations encourage swelling and water retention (MacEwan and Wilson 1980). In comparison with other available cations within sediments $(\mathrm{Na}$ and $\mathrm{Ca}$ ), the presence of large monovalent $\mathrm{K}^{+}$ions favors contraction of layers within the vacuum and higher temperature, when interacting with the electron beam of the electron microscope because $\mathrm{K}^{+}$bonds less strongly to solvated water. This explains why the smectite with higher $\mathrm{K}$ content observed during this study shows contracted layers in TEM images in contrast to the smectite with lower $\mathrm{K}$ content

3) The smectite is clearly heterogeneous in composition (Table 2) and in agreement with many previous AEM observations (Ahn and Peacor 1986). Such heterogeneity is consistent with a detrital origin or the earliest stages of diagenesis. Heterogeneity decreases as the grade of diagenesis increases (Peacor 1992).

\section{Diagenetic Changes}

Previous XRD studies concluded that with increasing depth R1 and R3 mixed-layered I/S and subsequently only $\mathrm{R} 3 \mathrm{I} / \mathrm{S}$ occur within the shaly part of the Basque-Cantabrian sequence (Aróstegui et al. 1991, 1993). Figure 6, obtained from sample UG-17, is representative of samples for which XRD indicates the presence of R1 and R3 I/S. It shows chlorite, calcite, $R 1 \mathrm{I} / \mathrm{S}$ with $50 \%$ illite layers and $\mathrm{R} \gg 3 \mathrm{I} / \mathrm{S}$ with more than $90 \%$ I layers in subparallel orientation. The two kinds of I/S detected by XRD coexist together with authigenic chlorite as separate units or packets. Such observations are tempered because illite-like and smectite-like layers could not be differentiated from most images. However, they are compatible with some recent observations by Kim et al. (1995) and Dong (personal communication, 1994) of R1 I/S coexisting with illite from Gulf Coast samples, where layers could be differentiated.

The classic study by Hower et al. (1976) of the smectite to illite transition within Gulf Coast mudstones provided the general idea that the transition occurred progressively without significant change of clay morphology. However, using direct TEM observations, Freed and Peacor (1992) showed that the transformation occurred by dissolution of smectite and crystallization of new I/S crystals. The data of this study are consistent with such an interpretation. In other words, the samples are dominated by two near-endmembers - R1 I/S with equal numbers of I and S layers and material with very few smectite-like interlayers. Only the latter material occurs within the deepest portions of the sediment sequence.

Data presented in Table 3 and Figure 9 demonstrate that there is extreme heterogeneity of $\mathrm{R} 1 \mathrm{I} / \mathrm{S}$ within samples. The differences in composition between individual grains of the same sample are as significant as the differences between different samples. However, illite from the deepest sample, in which only illite occurs, is relatively homogeneous. This is in keeping with the general trend of shale diagenesis toward a small number of relatively homogeneous phases (Peacor 1992).

Taken together, the XRD, HRTEM and AEM data show that the dioctahedral clay minerals from the 
shales consist of mixtures of different proportions of R1 and R>3 (illite with few smectite layers) I/S. Assuming that original reactant smectite was unstable, the products are consistent with an Ostwald-step-rule controlled process in which the result of the reaction is not a unique stable phase but a mixture of various heterogeneous intermediate metastable phases (Morse and Casey 1988, Figure 5). The heterogeneity of the AEM data for the mixed-layer samples is in part a consequence of inclusion of different proportions of $\mathrm{R} 1 \mathrm{I} / \mathrm{S}$ and $\mathrm{R} \gg 3$ illite from microanalysis areas combined with heterogeneity of the individual materials. R1 I/S was detected by XRD of samples from the upper part of the sequence but with increasing depth only illite was observed. This is inferred to be a result of increased temperature to a value permitting reaction kinetics to favor the "more stable" $\mathrm{R} \gg 3$ illite.

The different proportions of R1 I/S and R $\gg 3$ illite mixtures produce XRD patterns interpreted as indicating material that is progressively richer in illite layers. The illite represents the last step of the Ostwald-steprule sequence, preceding the formation of the stable phase, white mica (muscovite or phengite). It is still heterogeneous in composition, but clearly more homogeneous than the I/S from shallower (lower temperature) samples. The mean mixed-layer composition for each sample becomes progressively K-rich (Table 4 , Figure 10 ) as a consequence of the temperaturecontrolled proportion of $R 1 \mathrm{~L} / \mathrm{S}$ versus $\mathrm{R} \gg 3$ illite. A maximum value of $\Sigma_{\text {int }}=0.8$ is eventually reached when true illite is developed as the only authigenic dioctahedral clay mineral.

As noted above, the Basque-Cantabrian sequence is unique in that it includes $8000 \mathrm{~m}$ of sediments for which only burial metamorphic (non-tectonically-induced) effects can be observed. Assuming a normal geothermal gradient, the deepest sediments would have been subjected to a temperature of $200{ }^{\circ} \mathrm{C}$. From XRD data, the illite found at this depth appears to have few or no smectite interlayers. The absence of smectite interlayers is confirmed by HRTEM images of material from sample CG-5 and we conclude that the mineral corresponds to ideal illite. Nevertheless, the illite still has characteristics that identify it as immature in comparison to muscovite. The stacking sequence is largely disordered with ill-defined non-(001) reflections and streaking parallel to $\mathrm{c}^{*}$ in SAED patterns. It can therefore be differentiated from more mature and evolved micas. Although some tendency to 1 - or 2-layer periodicity can be discerned, such SAED patterns are typical of those that Baxter and Peacor (1991) described as diagnostic of $\mathrm{I} / \mathrm{S}$ or $\mathrm{I}$ in its initial state of formation and for which the polytype designation $1 \mathrm{M}_{\mathrm{d}}$ was used. The net negative charge is derived both from a range of $\mathrm{Al}$ substitutions for $\mathrm{Si}$ and $\mathrm{Mg}$ and $\mathrm{Fe}$ substitutions for ${ }^{[\mathrm{VI}]} \mathrm{Al}$, but the charge is typical of illite (approximately $0.8 \mathrm{pfu}$ ) and significantly less than the ideal value of nearly 1 for mature mica. Individual discrete packets are small (see below), a few tens of layers in thickness, and tend to be imperfect with a high density of layer terminations.

Prograde sequences have been studied from the Gaspé Peninsula by Jiang et al. (1994) and from Wales by $\mathrm{Li}$ et al. (1994). They found that the lowest grades belong to the upper zone of diagenesis, extending through the epizone, and prograde changes were caused by tectonic stress. In other words, the lowest temperature portions of these sequences overlap the highest temperature portion of the Basque-Cantabrian sequence. These authors observed transitions from illite-rich material with characteristics similar to those described above to mature micas and inferred that the transition represents a step (it is "episodic") triggered by tectonic activity. We conclude that the Basque-Cantabrian sequence is representative of the limits of passive burial metamorphism, at least insofar as transitions involving dioctahedral phyllosilicates are concerned, and that the deepest portions of the section overlap the conditions for tectonically-affected shale and slate sequences such as those described by Jiang et al. (1994) and $\mathrm{Li}$ et al. (1994). For the BasqueCantabrian Basin, the burial temperature in the absence of tectonic stress could not cause any significant mineral changes, such as illite-phengite reaction, the $1 \mathrm{M}_{\mathrm{d}}-2 \mathrm{M}$ polytype transformation, or the change in crystal outline of SAED patterns, which have retained the turbostratic stacking order.

From the KI values (Figure 1-III), the transition to the anchizone occurs within the deepest portions of the sequence, approximately at depths corresponding to illite-bearing samples such as CG-5. The anchizone concept is based on the Kübler crystallinity index (Kübler 1968; Frey 1987), but recently different interpretations have been determined regarding the physical meaning of the crystallinity index. Even though we did not carry out detailed measurements of the illite packet sizes seen in the TEM images of sample CG-5, they are clearly thinner than the $200 \AA$ (Figure 7) value given by Merriman et al. (1990) and Nieto and Sánchez Navas (1994) as representative of the diagenesis-anchizone transition. For the Basque-Cantabrian sequence, XRD and HRTEM data demonstrate that a high proportion of detrital mica is present in the $<2$ $\mu \mathrm{m}$ fraction. Therefore the $10 \AA$ peak of XRD patterns represents the sum of peaks for authigenic illite and the relatively more crystalline detrital mica. Even though the contribution of detrital micas is minimized by using fine grain sizes, the Basque-Cantabrian shales are unusual as having large proportions of detrital micas. The small size fractions therefore contain not only very thin grains of authigenic clays, but also an unusually high proportion of detrital grains or cleaved detrital grains. The resulting peak widths are smaller than would be the case for pure authigenic illite. 
Intergrowths of Na-Rich/K-Rich Authigenic Material

The processes by which $\mathrm{Na}$ and $\mathrm{K}$ are partioned into two coexisting dioctahedral phyllosilicates within low grade metamorphic rocks are still not well understood. Paragonite is generally considered an index mineral for the anchizone (Frey 1987). However, Li et al. (1994) have shown that it coexists with K-rich mica in grades as low as that of the diagenesis zone for a prograde sequence of pelites from Wales. Within those rocks, it is preceded by immature dioctahedral illitelike material in which there is a wide range of $\mathrm{Na} / \mathrm{K}$ solid solution corresponding to metastable single phases falling within the muscovite-paragonite solvus. Jiang et al. (1993) have observed similar metastable solid solutions in contact metamorphic rocks.

To our knowledge, the samples described above represent the lowest-grade example of $\mathrm{Na}$ - and $\mathrm{K}$-rich phyllosilicate intergrowths that have yet been observed. Although lattice fringe images showing ordering of smectite and illite layers could not be observed, they occur within the same samples and in close association with well-defined mixed-layered I/S. We tentatively infer that the coexisting $\mathrm{Na}$ - and $\mathrm{K}$-rich packets represent similar immature materials.

\section{Chlorite Composition Relation to the "Chlorite" Geothermometer}

Both detrital and authigenic chlorites are present in the Basque-Cantabrian samples. Even though origin could not be definitively ascertained for all chlorite grains, when the detrital character was obvious, chemical and structural signs of partial alteration to expandable trioctahedral layers (corrensite or smectite ?) were ubiquitous. The presence of a small proportion of 10 Å layers (collapsed smectite-like interlayers) resulted in distinctive chemical characteristics that differed from the composition of true chlorite (Table 5). Even high resolution AEM analyses may show the presence of alkalis in interlayer sites, an excess of ${ }^{[\mathrm{VI}]} \mathrm{Al}$ relative to ${ }^{[\mathrm{IV}]} \mathrm{Al}$, and significant numbers of octahedral vacancies when formulae are normalized to anions. Conversely, some chlorite occurs as small packets intergrown with mixed-layered I/S and illite and is free of signs of alteration. Such chlorite is inferred to be authigenic in origin. Its unique character relative to chlorite that is clearly detrital is also reflected since all analyzed grains had ideal chlorite formulae. Authigenic chlorite grains are rather homogeneous in composition, the sum of octahedral cations is almost $6 \mathrm{pfu}, \mathrm{Fe}$ is the principal octahedral cation, and the ${ }^{[\mathrm{V}]} \mathrm{Al}$ content is similar to that of ${ }^{\left[{ }^{[V]}\right]} \mathrm{Al}$.

Composition variations of low-grade chlorite have been directly related to temperature (Cathelineau and Nieva 1985; Noack et al. 1987). The "geothermometer" relationship described by Cathelineau and Nieva for "chlorite" from a geothermal field is based on chemical analyses for which the sum of the octahedral cations is less than six. Normalized formulae show an inverse correlation between the number of vacancies and temperature. The total of octahedral cations reaches 6 pfu only for grades corresponding to the greenschist facies. The chlorite analyses of Cathelineau and Nieva display the same characteristics as the "chlorite" analyses of the partially altered detrital chlorite that were described above. Shau et al. (1990) emphasized the same relationships for chlorite with expandable interlayers derived through alteration of marine basalts. They concluded that the "chlorite" geothermometer is not a valid geothermometer because it is based not on the presence of compositional variations from thermodynamically stable chlorite, but on the relative proportion of expandable layers for a complex mixed-layered trioctahedral phase. In other words, the "chlorite" is not chlorite. Shau et al. (1990) and more recently Jiang et al. (1994) argued that the decreasing proportion of expandable layers (and resulting composition change) for a prograde sequence is a measure of "reaction progress" toward the stable phase (chlorite), but most certainly is not an absolute measure of temperature because heterogeneous mixed-layer material is chemically metastable. Our results for the Basque-Cantabrian trioctahedral phylloslicates show, by contrast, that the same compositional relationships described by Cathelineau and Nieva exist for alteration products of originally-detrital chlorite. The authigenic chlorite shows no such composition change with increasing diagenetic grade even though the difference in depth between samples CO-31 and CG-5 is $6500 \mathrm{~m}$ and corresponds to a temperature difference of approximately $200{ }^{\circ} \mathrm{C}$. These observations demonstrate that changes in chlorite composition as a function of grade must be viewed with extreme caution unless they can be shown directly by TEM to have been obtained from true chlorite. They also imply that the geothermometer defined by Cathelineau and Nieva is not a valid geothermometer.

\section{CONCLUSIONS}

The interlayer charge and, in particular, the potassium content of the smectites are exceptionally high. The smectites presenting lower negative charge and lower interlayer cation contents are non-contracted from the vacuum and high temperature of TEM as opposed to the contracted smectites, which have higher charge and interlayer cation content. To our knowledge, this is the first time that the variable behavior of smectite from TEM images has been explained.

The illite is the last step for an Ostwald-step-rule sequence that precedes the formation of white mica, the stable phase. The average composition of the $\mathrm{V} / \mathrm{S}$ mixed-layered for each sample becomes gradually richer in $\mathrm{K}$, since temperature controls the proportion of $R 1 \mathrm{I} / \mathrm{S}$ versus $\mathrm{R} \gg 3$ illite, which have been distin- 
guished in high resolution images for the first time in this paper.

The Basque-Cantabrian Basin is a good example of the limits of passive burial metamorphism in which the deepest part of the type-sequence presents conditions equivalent to the shallowest part of tectonicallyaffected shale and slate sequences. $\mathrm{Na}$ - and $\mathrm{K}$-rich phyllosilicate intergrowths were detected from this basin within samples belonging to the lowest grade so far located. Differences were not detected (or do not exist) for the chemical composition of chlorites in samples separated by $6500 \mathrm{~m}$ in depth. Nonetheless, when the chlorites present low octahedral cation and ${ }^{\mathrm{VI}} \mathrm{Al}>{ }^{\mathrm{IV}} \mathrm{Al}$ contents, these characteristics are related to the formation of expandable layers within detrital chlorite. Previously reported compositional variations of chlorite depending on grade must therefore be considered with great caution.

\section{ACKNOWLEDGMENTS}

This manuscript benefitted from the careful revision of R.L. Burtner. This paper has been supported by Projects PB920961, PB92-0960 and BE90-234 grant to F. Nieto (DGICYT, Spain), Research Group of the Junta de Andalucía no. 4065 and NSF grant EAR-9104565 to D.R. Peacor. We are grateful to W-T Jiang and Y-H Shau for help in the use of the STEM and for discussion concerning interpretations of data.

\section{REFERENCES}

Ahn JH, Peacor DR. 1986. Transmission electron microscope data for rectorite: Implications for the origin and structure of "fundamental particles". Clays \& Clay Miner 34:180186.

Amiot M, Floquet M, Mathey B, Pascal A, Salomon J. 1982. Evolution de la marge cantabrique et son arrière-pays iberique au Crétacé. Cuad Geol Ibérica 8:37-63.

Aróstegui J, Zuluaga MC, Velasco F, Ortega Huertas M, Nieto F. 1991. Diagenesis of the Central Basque-Cantabrian basin (Iberian Peninsula) based on illite-smectite distribution. Clay Miner 26:535-548.

Aróstegui J, Nieto F, Ortega Huertas M, Velasco F, Zuluaga MC. 1993. Mineralogía de arcillas y grado de diagénesis del Cretácico Inferior, en el flanco sur del anticlinorio de Bilbao. Est Geol 49:277-286.

Baxter SM, Peacor DR. 1991. TEM observations of polytypism in illite. Clays \& Clay Miner 39:540-550.

Bell TE. 1986. Microestructure in mixed-layer illite/smectite and its relationship to the reaction of smectite to illite. Clays \& Clay Miner 34:146-154.

Boles JR, Franks SG. 1979. Clay diagenesis in Wilcox sandstones of Southwest Texas: implications of smectite diagenesis on sandstone cementation. J Sediment Petrol 49: 55-70.

Buatier MD, Peacor DR, O'Neil JR. 1992. Smectite-illite transition in Barbados accretionary wedge sediments: TEM and AEM evidence for a dissolution/crystallization origin at low temperature. Clays \& Clay Miner 40:65-80.

Cathelineau M, Nieva D. 1985. A chlorite solid solution geothermometer. The Los Azufres (Mexico) geothermal system. Contrib Mineral Petrol 91:235-244.

Chamley H. 1989. Clay Sedimentology. Berlin: Springer. $620 \mathrm{p}$.

Champness PE, Cliff G, Lorimer GW. 1981. Quantitative analytical electron microscopy. Bull Mineral 104: 236-240.
Cliff G, Lorimer G W. 1975. The quantitative analysis of thin specimens. J Microsc 103:203-207.

Crowley SF. 1991. Diagenetic modification of detrital muscovite: An example from the Great Limestone Ciclotem (Carboniferous) of Co. Durham, UK. Clay Miner 26:91103.

Deregnaucourt D, Boillot G. 1982. Structure géologique du golfe de Gascogne. Bull du BRGM 2:149-178.

Dickens G. 1994. Personal communication. Department of Geological Sciences, The University of Michigan, 1006 CC. Little Building, Ann Arbor, MI 48109-1063.

Dong H. 1994. Personal communication. Department of Geological Sciences, The University of Michigan, 1006 CC. Little Building, Ann Arbor, MI 48109-1063.

Eberl DD. 1993. Three zones for illite formation during burial diagenesis and metamorphism. Clays \& Clay Miner 41: 26-37.

Foscolos AE, Powell TG, Gunther PR. 1976. The use of clay minerals and inorganic and organic geochemical indicator for evaluating the degree of diagenesis and oil generating potential of shales. Geochim Cosmochim Acta 40:953-966.

Freed R L, Peacor D R. 1992. Diagenesis and the formation of authigenic illite-rich crystals in Gulf Coast shales: TEM study of clay separates. J Sediment Petrol 62:220-234.

Frey M. 1987. Very low-grade metamorphism of clastic sedimentary rocks. In: Frey M, editor. Low temperature metamorphism. London: Blackie. p 9-58.

Guthrie GD, Veblen DR. 1989. High resolution transmission electron microscopy of mixed-layer illite/smectite: Computer simulations. Clays \& Clay Miner 37:1-11.

Heling D. 1978. Diagenesis of illite in argillaceous sediments of the Rhine Graben. Clay Miner 13:211-219.

Hower J, Eslinger E, Hower ME, Perry EA. 1976. Mechanism of burial metamorphism of argillaceous sediments: 1 . Mineralogical and chemical evidence. Geol Soc Am Bull 87:725-737.

Islam S, Hesse R, Chagnon A. 1982. Zonation of diagenesis and low-grade metamorphism in Cambro-Ordovician flysch of Gaspé Peninsula, Quebec Appalachians. Can Mineral 20:155-167.

Jennings S, Thompson GR. 1986. Diagenesis of Plio-Pleistocene sediments of the Colorado River delta, Southern California. J Sediment Petrol 56:89-98.

Jiang WT, Essene EJ, Peacor DR. 1990. Transmission electron microscopic study of coexisting pyrophyllite and muscovite: direct evidence for the metastability of illite. Clays \& Clay Miner 38:225-240.

Jiang WT, Peacor DR. 1993. Formation and modification of metastable intermediate $\mathrm{Na}-\mathrm{K}$ mica, paragonite, and muscovite in hydrothermally altered metabasites from North Wales. Am Mineral 78:782-793.

Jiang WT, Peacor DR, Buseck PR. 1994. Chlorite Geothermometry?-Contamination and Apparent Octaheddral Vacancies. Clays \& Clay Miner 42:593-605.

Kim JW, Peacor DR, Tessier D, Elsass F. 1995. A technique for maintaining texture and permanent expansion of smectite interlayers for TEM observations. Clays \& Clay Miner 43:51-57

Kretz R. 1983. Symbols for rock forming minerals. Am Miner 68:277-279.

Kübler B. 1968. Evaluation quantitative du metamorphisme par la cristallinité de l'illite. Bull Centre Rech Pay-S.N.P.A. 2:385-397.

Lanson B, Champion D. 1991. The I/S-to-illite reaction in the late stage diagenesis. Am J Sci 291:473-506.

Li G, Peacor DR, Merriman RJ, Roberts B. 1994. The Diagenetic to Low-Grade Metamorphic Evolution of Matrix White Micas in the System Muscovite-Paragonite in a Mu- 
drock from Central Wales, United Kingdom. Clays \& Clay Miner 42:369-381.

Lindgreen H, Hansen PL. 1991. Ordering of illite-smectite in Upper Jurassic claystones from the North Sea. Clay Miner 26:105-125.

López Munguira A, Nieto F, Sebastián E, Velilla N. 1991. The composition of phyllosilicates in Precambrian, lowgrade-metamorphism, clastic rocks from the Southern Hesperian Massif (Spain) used as indicator to metamorphic conditions. Precambrian Res 53:267-279.

MacEwan DMC, Wilson MJ. 1980. Interlayer and intercalation complexes of clay minerals. In: Brindley GW, Brown $\mathrm{G}$, editors. Crystal structures of clay minerals and their $X$-ray identification. London: Miner Soc. p 197-248.

Massone HJ, Schreyer W. 1987. Phengite geobarometry based on the limiting assemblage with $\mathrm{K}$-feldspar phlogopite and quartz. Contr Mineral Petrol 96:212-224.

Merriman RJ, Roberts B. 1985. A survey of white mica crystallinity and polytypes in pelitic rocks of Snowdonia and Llyn, North Wales. Miner Mag 49:305-319.

Merriman RJ, Roberts B, Peacor DR. 1990. A transmision electron microscope study of white mica crystallite size distribution in a mudstone to slate transitional sequence, North Wales, U.K. Contr Mineral Petrol 106:27-40.

Morse JW, Casey WH. 1988. Ostwald processes and mineral paragenesis in sediments. Am J Sci 288:537-560

Nadeau PH, Wilson J, McHardy W, Tait JM. 1985. The conversion of smectite to illite during diagenesis: evidence from some illitic clays from bentonites and sandstones. Min Mag 49:393-400

Nieto F, Sánchez Navas A. 1994. XRD/TEM comparative study on the physical meaning of white mica "cristallinity" index. Eur J Min 6:611-621.

Noack Y, Giroir G, Girard JP. 1987. Chlorites as indicators of paleoenvironments. In: Rodríguez Clemente R, Tardy $\mathrm{Y}$, editors. Geochemistry and mineral formation in the earth surface. Madrid: C.S.I.C. p 639-652.
Peacor DR. 1992. Diagenesis and low-grade metamorphism of shales and slates. In: Buseck P, Ribbe PH, editors. Reviews in Mineralogy. Chelsea: Miner Soc Am. 27:335-380.

Perry E, Hower J. 1970. Burial diagenesis in Gulf coast pelitic sediments. Clays \& Clay Miner 18:165-177.

Powers MC. 1967. Fluid release mechanisms in compacting marine mudrocks and their importance in oil exploration. A.A.P.G. Bull 51:1240-1254.

Ramseyer K, Boles JR. 1986. Mixed-layer illite/smectite minerals in Tertiary sandstones and shales, San Joaquin basin, California. Clays \& Clay Miner 34:115-124.

Reynolds RC. 1980 . Interstratified clay minerals. In: Brindley GW, Brown G, editors. Crystal Structures of clay minerals and their X-ray identification. London: Miner Soc. $p$ 249-304.

Shau YH, Peacor DR, Essene EJ. 1990. Corrensite and mixed-layer chlorite/corrensite in metabasalt from northern Taiwan: TEM/AEM, EMPA, XRD, and optical studies. Contrib Mineral Petrol 105:123-142,

Shau YH, Feather ME, Essene EJ, Peacor DR. 1991. Genesis and solvus relations of submicroscopically intergrown paragonite and phengite in a blueschist from northern California. Contrib Mineral Petrol 106:367-378.

Srodon J, Eberl D. 1984. Illite. In: Bailey SW, editor. Reviews in Mineralogy. Chelsea: Miner Soc Am. 13:495-544.

Suchecki RK, Perry EA, Hubert JF. 1977. Clay petrology of Cambro-Ordovician continental margin, Cow Head Klippe, Western Newfoundland. Clays \& Clay Miner 25:163-170.

Van Der Pluijm BA, Lee JH, Peacor DR. 1988. Analytical electron microscopy and the problem of potassium diffusion. Clays \& Clay Miner 36:498-504.

Yau YC, Peacor DR, McDowell SD. 1987. Smectite-to-illite reactions in Salton Sea shales; a transmission and analytical electron microscopy study. J Sediment Petrol 57:335-342.

(Received 13 October 1994; accepted 14 July 1995; Ms. 2584). 